\title{
SO HELP ME GOD: A COMPARATIVE STUDY OF RELIGIOUS INTEREST GROUP LITIGATION
}

\author{
Jayanth K. Krishnan* \& Kevin R. den Dulk**
}

We seek to account for why religious groups in the United States during the past three decades have increasingly turned to the courts to achieve their public policy goals. Most conventional theories of organized rights advocacy in the courts suggest that groups mobilize as a rational response to their political environment or the availability of resources.

While recognizing the importance of such factors, our study contends that an important ideational variable has been left out of the analysis. We argue that the changing attitudinal and normative orientations about the law and its potential implications shape the decision-making process of religious organizations and are critical for whether courts are used as a means for pursuing policy goals.

To test the robustness of our theory, not only do we focus on religious groups in the United States, but we also look at the activities of such organizations in two other countries, Israel and India. Because of the important variations Israel and India offer in terms of religious legal mobilization, both countries serve as methodologically key cases for our comparative study. Our conclusion is that the significance of the ideational variable transcends national boundaries and therefore should be seriously considered by future scholars who study law, religion, and legal advocacy.

* Assistant Professor of Law, William Mitchell College of Law, St. Paul, MN. J.D., Ohio State University; M.A., University of Wisconsin-Madison; Ph.D., University of WisconsinMadison.

** Assistant Professor of Political Science, Grand Valley State University, Allendale, MI. M.A., University of Wisconsin-Madison; Ph.D., University of Wisconsin-Madison.

The authors would like to thank Bert Kritzer, Marc Galanter, Don Downs, and the Law Faculties at Hebrew University and the University of Delhi. This research was funded by grants from the Charlotte Newcombe Foundation and the U.S. Department of Education. This research was funded by grants from The Charlotte Newcombe Foundation[, the Civitas Program in Faith and Public Affairs,] and the U.S. Department of Eduction. 
CONTENTS

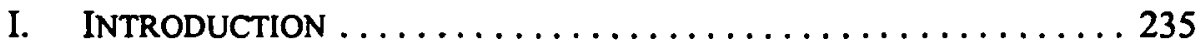

II. EXPLANATORY FRAMEWORK . . . . . . . . . . . . . . . . . 239

A. The Nature of the Political System .............. 239

B. Resource Mobilization ..................... 242

C. Political Disadvantage and Other Institutional

Considerations ................................. 244

D. An Alternative Consideration: Ideas . . . . . . . . . . 246

III. RELIGION AND LITIGATION IN THE UNITED STATES: TWO RELIGIOUS TrAdITIONS ................................. 248 A. The Rise in Legal Advocacy Within the Evangelical

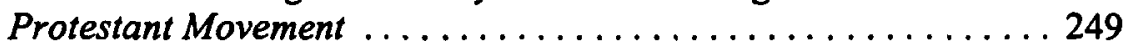

B. Legal Advocacy Within the Roman Catholic Movement ..... 253

IV. RELIGIOUS INTEREST GROUP LITIGATION IN ISRAEL AND INDIA . 259

A. The Power of Ideas in a Comparative Context . . . . . . . 262

1. The Case of Israel ..................... 262

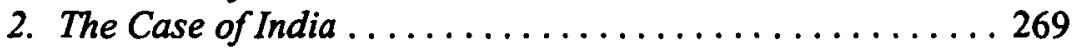

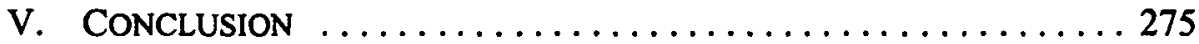




\section{INTRODUCTION}

It is no accident that religious groups are important political actors in many modern democracies.' Most of these democracies were carved out of diverse religious populations, and immigration patterns have only added to the mix. Hence the political systems in these nation-states have had to cope with the peculiar demands of religious citizens-demands which these citizens often voice loudly and with some force in court. ${ }^{2}$ Legal advocacy by religious groups, however, is not a self-evident choice as a form of participation. After all, modern democracies usually offer organizations multiple points of political access. $^{3}$ Moreover, some religious groups might choose to avoid political confrontation altogether, perhaps for uniquely religious reasons. ${ }^{4}$

Our purpose in this article is to examine the factors determining the choice to litigate among religious groups in the United States, Israel, and India. We

1 The literature on this subject is of course immense. For a selected set of works, see generally STEPHEN CARTER, GOD'S NAME IN VAIN: THE WRONGS AND RIGHTS OF RELIGION IN POLITICS (2000); DONALd SMITH, RELIGION AND POLITICAL DEVELOPMENT (1970); JEFFREY HAYNES, RELIGION IN THIRD WORLD POLITICS (1993); DANIEL PIPES, IN THE PATH OF GOD: ISLAM AND POLITICAL POWER (1983); ROBERT BOOTH FOWLER ET AL., RELIGION \& POLITICS IN AMERICA (1999); MARTIN MARTY \& R. SCOTT APPLEBY, THE FUNDAMENTALISM PROJECT (1991); STEPHEN MONSMA \& J. CHRISTOPHER SOPER, THE CHALLENGE OF PLURALISM: CHURCH AND STATE IN FIVE DEMOCRACIES (1997).

${ }^{2}$ See, e.g., Marc Galanter \& Jayanth K. Krishnan, Personal Law and Human Rights in India and Israel, 34 ISR. L. ReV. 98 (2000); MARTIN EDELMAN, COURTS, POLITICS AND

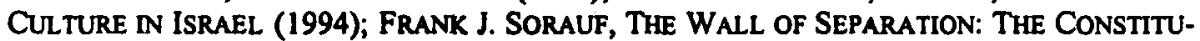
TIONAL POLITICS OF CHURCH AND STATE (1976); ANDREW KOSHNER, SOLVING THE PUZZLE OF INTEREST GROUP LITIGATION (1998); KEVIN DEN DULK, PROPHETS IN CAESAR'S COURT: THE ROLE OF IDEAS IN CATHOLIC AND EVANGELICAL RIGHTS ADVOCACY (2001) (unpublished Ph.D dissertation, University of Wisconsin-Madison) (on file with authors); Gregg Ivers, Please God. Save this Honorable Court, in THE INTEREST GROUP CONNECTION: ELECTIONEERING, LOBBYING AND POLICYMAKING IN W ASHINGTON (Paul Hermson ed., 1998) [hereinafter Ivers, Please God].

'In the American context this point has been empirically, as well as theoretically demonstrated by several scholars of organizations. See, e.g., KAY SCHLOZMAN \& JOHN TIERNEY, ORGANIZED INTERESTS AND AMERICAN DEMOCRACY 150 (1986); JEFFREY BERRY, LOBBYING FOR THE PEOPLE 212-52 (1977). For other studies on this subject, see JOHN P. HEINZ et al., The Hollow Core: Private INTERests in National POlicymaking 63-69 (1993); Anthony Nownes \& Patricia Freeman, Interest Group Activity in the States, 60 J. POL. 88, 92 (1998); Thomas L. Gais \& Jack L. Walker Jr., Pathways to Influence in American Politics, in MOBILIZING INTEREST GROUPS IN AMERICA: PATRONS, PROFESSIONS, AND SOCIAL MOVEMENTS 104-11 (Jack L. Walker Jr. ed., 1991).

4 This tendency has been especially well-documented by historians of fundamentalism in the United States. See generally JOEL CARPENTER, REVIVE US AGAIN: THE REAWAKENING OF AMERICAN FUNDAMENTALISM; GEORGE MARSDEN, UNDERSTANDING FUNDAMENTALISM AND EVANGELICALISM (1991). 
choose these three countries for important legal and methodological reasons. Each is a modern democracy with a long history of addressing religious matters in civil courts. ${ }^{5}$ Due to British influence, each legal system owes much to the common law tradition, and India and Israel have also patterned portions of their legal systems after the American model. ${ }^{6}$ Each contains a diverse religious population, albeit to varying degrees. ${ }^{7}$ Yet there are also important differences among these nations, and analyzing these differences helps us better understand the myriad forces propelling and/or hindering religious groups in asserting their demands in courts. ${ }^{8}$

5 The literature on this issue also is quite vast. For a selected set of works in the U.S., see generally JOHN WITTE JR, RELIGION AND THE AMERICAN CONSTITUTIONAL EXPERIMENT: ESSENTIAL RIGHTS AND LIBERATION (2000); GREGG IVERS, TO BUILDA WALL: AMERICAN JEWS AND THE SEPARATION OF CHURCh AND STATE (1995) [hereinafter, IVERS, TO BUILD A WALL]. For a selected set of works on India, see generally MARC GALANTER, COMPETING EQUALITIES: LAW AND THE BACKWARD Classes IN INDIA (1984) [hereinafter, GALANTER, COMPETING EQUALITIES]; MARC GalaNTER, LAW AND SOCIETY IN MODERN INDIA (1989) [hereinafter, GALANTER, LAW AND SOCIETY INMODERN INDLA]; J.D.M. DERRETT, ESSAYS IN CLASSICAL AND MODERN HINDU LAW (1978); J.D.M. DERRETT, RELIGION, LAW AND THE STATE IN INDIA (1968); Rajeev Dhavan, Religious Freedom in India, 25 AM. J. COMP. L. 209 (1987). For Israel, see EDELMAN, supra note 2; Izhak Englard, Law and Religion in Israel, 25 AM. J. COMP. L. 125 (1987).

- See generally GRANVILle Austin, THE INDIAN CONSTITUTION: CORNERSTONE OF A NATION (1999); Galanter \& Krishnan, supra note 2; GALANTER, LAW AND SOCIETY IN MODERN INDIA, supra note 5; IZHAK ENGLARD, RELIGIOUS LAW IN THE ISRAELI LEGAL SYSTEM (1975); EDELMAN, supra note 2; Marcia Gelpe, Constraints on Supreme Court Authority in Israel and the United States: Phenomenal Cosmic Power; Itty Bitty Living Space, 13 EMORY INT'L L. REV. 493 (1999).

7 In Israel the population is approximately six million people. Of the non-Jews, Muslims make-up nearly fifteen percent, Christians make up approximately two percent, and Druze comprise about 1.6 percent. See Israeli Central Bureau of Statistics, available at http://www. cbs.gov.il. In India, approximately $82 \%$ of the country is Hindu, $12 \%$ Muslim, and the remaining $6 \%$ of the country are divided among Christians, Sikhs, Buddhists, Jains, Parsees, and Jews. See Census of India, available at http://www.censusindia.net. White evangelical Protestants, mainline Protestants, and Catholics each comprise $20-25 \%$ of the population in the U.S., while the remaining citizens are divided among African American Protestants, Jews, Muslims, and smaller religious and non-religious groups. For a recent assessment, see ANDREW KOHUT ET AL., THE DIMNISHING DIVIDE: RELIGION'S CHANGNG ROLE IN AMERICAN POLITICS 16-33 (2000). It should be noted, however, that measuring patterns of religious identification is a notoriously difficult process. For a discussion on measurement problems in the U.S., see Kenneth Wald and Corwin Smidt, Measurement Strategies in the Study of Religion and Politics, in REDISCOVERING THE RELIGIOUS FACTOR IN AMERICAN POLITICS 26-49 (David Leege \& Lyman Kellstedt eds, 1993).

${ }^{8}$ For an excellent discussion on selection of cases and the importance of variation, see GARY KING ET AL., DESIGNING SOCIAL INQUIRY 129-30, 134, 214-17 (1994). For an interesting study that examines issues of religion and secularism within these three countries, see Gary $\mathrm{J}$. 
Our chief focus is legal advocacy through political litigation, that is, advancing broad policy goals by bringing conflicts directly to court for a resolution. ${ }^{9}$ Pursuing policy goals in court is rare in all three countries relative to other tactics, but it is nevertheless a factor in interest group politics. Nearly fifty years ago, U.S. Supreme Court Justice Robert Jackson declared it "government by lawsuit" and "the stuff of power politics in America," 10 and its use as a political tactic in the United States has only increased over time. Some scholars have argued that the same is true in Israel and India, though the evidence of the nature and extent of Israeli and Indian political litigation, as we shall see, is less developed in the law and courts literature.

Over time, scholars of law and politics have considered many explanations of interest group litigation, but most have focused on institutional and organizational factors that include: the role of organized groups in the political and legal system, the available legal resources of those groups, and the properties of courts that make them attractive advocacy sites. "Each of these factors has well-documented effects on the legal mobilization of organized groups in the United States and abroad, and we do not wish to underestimate their role in structuring the choice to litigate. We argue, however, that another determinant is often omitted from analyses of litigation campaigns. We suggest that adding an ideational factor-that is, the normative and explanatory ideas of the groups themselves-provides a particularly rich insight into motivations for litigation. Ideas reconfigure the strategic terrain: groups see their resources and political environment through a distinctive worldview that influences their political litigation efforts.

Jacobsohn, Three Models of Secular Constitutional Development: India, Israel, and the United States, 10 STUD. AM. POL. DEV. 1 (1996).

"We are very sensitive to the fact that there are various definitions to the term "litigation." For works that discuss litigation through the filing of lawsuits, see Lee Epstein \& C.K. Rowland, Debunking the Myth of Interest Group Invincibility in the Courts, 85 AM. POL. SCI. REV. 205 (1991); LEE EPSTEN, CONSERVATIVES IN COURT 68 (1985). For an important study that discusses the amici aspect to litigation, see James F. Spriggs \& Paul J. Wahlbeck, Amicus Curiae and the Role of Information at the Supreme Court, 50 POL. RES. Q. 365 (1997). And for works that discuss litigation in terms of class action suits or through the sponsorship of a third party lawsuit, see generally Kim Lane Scheppele \& Jack L. Walker, The Litigation Strategies of Interest Groups, in MOBILIZING INTEREST GROUPS IN AMERICA 180-81 (Jack L. Walker ed., 1991) [hereinafter Scheppele \& Walker, Litigation Strategies]; IVERS, To BUILD A WALL, supra note 5 .

${ }^{10}$ ROBERT JACKSON, THE STRUGgLE FOR JUdICIAL SUPREMACY: A STUDY OF A CRISIS IN AMERICAN POWER POLITICS 287 (1951).

"We develop and provide a thorough literature review of these explanations in the next section of our article. 
A note on methodology: As scholars of American and comparative law know all too well, sources of data can vary widely among different points of comparison under study. For several reasons, our analysis is no exception. First, as we shall discuss, in the United States the courts are relatively open with information about participants in litigation efforts. Indeed, the identities of participants, as well as the contents of the primary and amicus briefs they file, are readily available. Second, U.S. group leaders and activists are often more accessible than in many places abroad, where matters ranging from geographical isolation to political persecution might hamper researcher access. In some ways India and Israel presented such impediments to the data gathering and analysis represented in this study. Finally, though it would be ideal to compare litigation efforts across similar policy areas, religious groups in each country face unique cultural and policy challenges that do not easily correspond to group experiences elsewhere.

Attending to these research issues forces us to use somewhat different methodological approaches with respect to each country. Yet the study does provide uniformity across cases by relying primarily on interviews and archival sources of data of groups that have emerged in recent decades as litigators in the political arena. Each case study of national religious groups reveals its own mix of motives and opportunities for political litigation, but several themes develop across the cases that suggest particular combinations of institutional, resource, and ideational factors are present when groups decide to mobilize the law through litigation.

We divide this article into several sections. Section two sets forth the theoretical debate currently on-going among scholars as to what affects whether groups use litigation as a policy tool. We first outline three of the more common explanations and then provide our perspective, one which takes into account an important factor that to-date has gone relatively unnoticed. In section three we apply our theory to two important religious organizations in the United States: Catholics and Evangelical Protestants. We outline how our theory best explains the rise of religious-based litigation by these two organizations. In section four we move to a discussion of religious-based groups in Israel and India. Like our argument for the United States, we contend that while the standard explanations matter in Israel and India for whether groups use litigation, equally important to the equation are the ideas and perceptions these groups have towards their own religious ideology. Section five offers a series of concluding remarks. We provide further questions of inquiry for future research and close by explaining why this study is an important contribution for those interested in examining how courts can be used for ideological purposes. 


\section{'II. EXPLANATORY FRAMEWORK}

In this section, we describe those institutional and organizational factors that scholars often propose as determinants of organized political litigation: the nature of the political system, the legal resources available to groups, and the opportunities for political advocacy available in non-judicial institutions. We then discuss some general expectations about an alternative framework, namely, the influence of religious ideas on the choice to litigate. Although these sets of factors interact in practice, for the sake of theoretical clarity it is helpful to consider them separately.

\section{A. The Nature of the Political System}

The structure of a democratic state's political system may fundamentally affect the type of interaction organizations have with government institutions. ${ }^{12}$ The American political system, for example, many believe represents a structure where numerous types of groups have the opportunity to influence policy. ${ }^{13}$ Government institutions in the U.S., the argument goes, serve as the playing fields for competing groups to stake their particular claims. ${ }^{14}$ The judiciary, of course, is an integral part of the American state, and it therefore serves as an important forum where numerous groups can compete to advance their policy goals. Accordingly, we should not be surprised to find groups within this type of system often engaging the courts.

The political systems of Israel and India are stark contrasts to what we find in the United States. Both Israel and India are strong multi-party systems; in

12 Many classic studies have developed this idea in great detail. For a sample of excellent discussions, see generally ARTHUR BENTLEY, THE PROCESS OF GOVERNMENT (1908); PETER H. Odegard, Pressure Politics: The Story of the ANTi-SaloOn League (1928); Robert Dahl, Who Governs? (1961); David Truman, The GovernMental Process: Political INTERESTS AND PUBlic OPINION (1951); GRANT MCCONNELl, PRIVATE POWER AND AMERICAN DEMOCRACY (1966).

${ }^{13}$ See, e.g., ERNEST S. GRIFFTH, THE IMPASSE OF DEMOCRACY 182.83 (1939) (noting that a group approach to understanding politics is key because it necessarily takes into consideration organizations at the grassroots level, such as labor movements, agricultural movements, and trade unions).

14 See FranK BAUMgaRTNER \& BeTH LeECH, Basic INTERESTS: THE IMPORTANCE OF GROUPS AND POLITICS IN POLITICAL SCIENCE 46-50 (1998) (summarizing this "pluralist" viewpoint of American politics that was dominant during several decades of the twentieth century). See generally TRUMAN, supra note 12; BENTLEY, supra note 12; David Greenstone, Group Theories, in MICROPOLITICAL THEORY: VOLUME 2, HANDBOOK OF POLITICAL SCIENCE, (Fred I. Greenstein \& Nelson Polsby eds., 1975). 
both cases interest groups must compete not only with each other, but also with powerful political parties when attempting to capture the attention of the state. ${ }^{15}$ As a result, groups are often "edged-out" by political parties and are unable to represent themselves in such state institutions as the legislature, bureaucracy, or judiciary. ${ }^{16}$ For example, in Israel parties control the legislative and bureaucratic branches of government, and as a consequence, control the distribution of social services as well. ${ }^{17}$ Parties serve as the main organizations that represent political interests; thus parties (rather than groups) are used as the vehicles for political mobilization. ${ }^{18}$ They also set much of the political agenda for the country, and the ruling party, in particular, frequently determines the degree of salience given to an issue. ${ }^{19}$ In addition, parties are present at almost every access point of influence in the political system. As Asher Arian notes:

Independent groups that organize to influence policy are generally short-lived and unsuccessful unless co-opted by some party-affiliated or government-affiliated group. More important, in the Israeli system the number of groups proves nothing because of their extreme inequality in terms of power. Power in the system is in the hands of leaders of the party or parties in the government coalition. ${ }^{20}$

15 For Israel, see ASHER ARIAN, THE SECOND REPUBLIC: POLITICSIN ISRAEL 141, 282 (1998) [hereinafter ARIAN, SECOND REPUBLIC]; ASHER ARIAN, POLITICS IN ISRAEL: THE SECOND GENERATION 206, 283 (2d ed. 1989) (hereinafter ARIAN, SECOND GENERATION]. For India, see generally ATUL KOHLI, THE STATE AND POVERTY IN INDIA: THE POLITICS OF REFORM (1987); SUNIL KHILNANI, THE IDEA OF INDIA (1998).

${ }^{16}$ For comparative works that examine the relationship between groups and parties, see generally HENRY EHRMANN, INTEREST GROUPS ON FOUR CONTINENTS (1958); GABRIEL

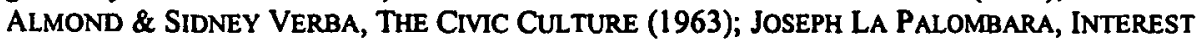
Groups IN ITALIAN POLITICS (1964); HARRY ECKSTEIN, PRESSURE GROUP POLITICS (1960); AREND LIJPHART, THE POLITICS OF ACCOMODATION: PLURALISM AND DEMOCRACY IN THE NETHERLANDS (1968); ROBERT PUTNAM, MAKING DEMOCRACY WORK: CIVIC TRADITIONS IN MODERN ITALY (1993).

17 See YaEl YishaI, LAND OF PARADOXES: INTEREST POLITICS IN ISRAEL 32 (1991).

18 See ITZHAK GALNOOR, STEERING THE POLITY: COMMUNICATIONS AND POLITICS IN ISRAEL 74-77, 163-64 (1982).

19 See ARIAN, SECOND REPUBLIC, supra note 15, at 141, 283.

${ }^{20} \mathrm{Id}$. at 289. 
In the context of political litigation, then, it would appear as though Israeli groups would need to rely on-if not defer to-the decisions and choices of stronger, ideologically similar political parties. ${ }^{21}$

In India, too, the presence of powerful parties, particularly the Congress Party, has affected what interest groups have been able to do. From the time of Independence (1947) to 1977, governmental power at the national level was under the leadership of the Congress Party. ${ }^{22}$ During this time Congress was the main possessor and distributor of resources. ${ }^{23}$ And although there were brief periods when Congress' authority came into question, no other party or organization really was in a position to challenge the seemingly invincible power, prestige, and effectiveness of India's preeminent party.

It was not until after the end of Indira Gandhi's Emergency Rule that India saw an increase in the number of interest groups and social movements. ${ }^{24}$ Yet, overall, the nature of the Indian political system has not lent itself to effective interest group mobilization. Little cohesion exists among Indian interest groups. ${ }^{25}$ There is high fragmentation and great disunity, even among groups within the same policy sphere. In addition, while parties possess at the very least some resources, most groups struggle to exist; not surprisingly the latter tend to be very ephemeral in nature. ${ }^{26}$ Groups are weak institutionally, and their bureaucracy often is inefficient and/or unstructured. ${ }^{27}$ The resilience of

${ }^{21}$ See YISHAI, supra note 17, at 133-34.

22 The Congress Party's roots trace back, ironically, to a type of interest organization known as the Indian National Congress (NC) that formed in the late 1800s. The INC was comprised primarily of educated, urban nationalists who originally demanded that the British allow more Indians to participate in the governing of colonial India. After decades of ignoring their requests, the INC, led by Mohandas Gandhi who helped bring millions of supporters to the INC's cause, eventually began pushing for independence. Upon the British's departure from India in 1947, the INC transformed into the Congress Party with Jawaharlal Nehru serving as the country's prime minister from 1947-1964. See KHILNANI, supra note 15.

${ }^{23}$ See generally Paúl BRASS, The NEW CAMBRIDGe History of INDIA THE POLITICS OF INDIA SINCE INDEPENDENCE (1990) (describing in detail the type of hold the Congress Party had on the social, political, and economic lives of Indians till 1977).

${ }^{24}$ Id. at 38-42. The Emergency Rule period lasted in India between 1975 and 1977. During these two years, Indira Gandhi suspended democracy and ruled by decree, arguing that the state faced a national security threat from opposition forces in the country. However, Paul Brass and many other scholars suggest that other self-interested factors caused her to suspend the Constitution. For example, the economy remained weak, public protests against her policies continued, opposition leaders called on the military to oust her from power, and she was convicted of corruption charges in a state court in Gujarat. See id.

${ }^{25}$ See CHARLES R. EPP, THE RIGHTS REVOLUTION: LAWYERS, ACTIVISTS, AND SUPREME COURTS IN COMPARATIVE PERSPECTIVE 98-99 (1998) [hereinafter RIGHTS REVOLUTION].

${ }^{26}$ See id.

${ }^{27}$ See id. 
a group frequently depends upon the personality, charisma, and reputation of one or two major leaders. ${ }^{28}$ It is rare to find a developed hierarchy or secondary set of administrators below these few important figures. ${ }^{29}$ Therefore, in India, with political parties continuing to have more power than their interest group counterparts, we would expect to find the types of strategies used by an organized group-including litigation-to be highly affected by the relationship it has with existing political parties.

\section{B. Resource Mobilization}

Money and expertise can be devoted to legal activity, the base constituency from which the organization can draw support, organizational structure, and the strength and coordination of pre-existing organizational networks. Each of these resources matter to whether and how organized groups will mobilize the law. ${ }^{30}$ Across the ideological spectrum, for example, we might expect that budgetary considerations would affect not only the choice to use legal advocacy, but also the form of legal advocacy a group employs. ${ }^{31}$ And, in the realm of U.S. appellate litigation, for example, groups with large budgets might choose the direct control of case sponsorship, while groups with smaller war chests might resort to the less costly amicus curiae brief. An organization's "sunk costs" in staff attorneys can help motivate use of courts as well. Other resources, such as a group's structure and leadership arrangement, can affect how it relates to supporters, how well it divides the labor of advocacy with other groups, and how effectively it chooses its battles.

There is a wealth of scholarship exploring the role of resources as a determinant of a group's choice to use litigation as an on-going political tactic. In his study of civil rights advocacy, for example, Stephen Wasby suggests that the significance of resources extends from broad strategizing to the nitty gritty of tactical decision-making. He maintains that "resources affect decisions to engage in lobbying, development of public opinion, and litigation; within litigation, decisions to litigate in particular areas of law; and, within those areas, decisions to pursue particular cases." "Lack of resources," he

${ }^{2 s}$ See id.

${ }^{29}$ See id.; see generally D.L. Sheth \& Harsh Sethi, The NGO Sector in India: Historical Context and Current Discourse, VolunTus 49 (1991) (discussing how the proliferation of NGOs in India has diminished the autonomy of these organizations from the government).

${ }^{30}$ See, e.g., EPP, supra note 25, at 58-61, 69-70.

${ }^{31}$ See Scheppele \& Walker, Litigation Strategies, supra note 9, at 176, 181.

32 STEPHEN WASBY, RACE RELATIONS LITIGATION IN AN AGE OF COMPLEXITY 76 (1995). 
continues, "both force[s] choices and limits them."33 In a comparative vein, Epp has argued that cross-national variations in the proliferation of rights are the result of a "support structure" in which lawyers and activists generate the material resources necessary to advance rights-agendas in court. ${ }^{34}$ Others have contended that individual or group access to distinctly legal resources-technical expertise, for example-provides a powerful alternative to certain institutional explanations of legal mobilization. ${ }^{35}$ Still others suggest that groups with abundant resources have some clear advantages over their competition. ${ }^{36}$ Numerous scholars have offered versions of what some call "party capability theory," which suggests that resources are often a key factor in litigation success in the U.S. and abroad. ${ }^{37}$

These resource-centered explanations for legal mobilization complement another set of arguments about the specific capacities of religious communities. These communities possess certain kinds of resources that help sustain rights-advocacy groups. Some resources are tangible and require relatively little participation in an organization (e.g. direct monetary contributions). But, there are also less tangible skills that ordinary religionists can (and do) transfer to public life. Verba, Schlozman, and Brady argue that religious groups maintain a "counterbalance" to corporations, universities, and other resourcerich organizations "by providing opportunities for the development of civic

33 Id. at 81 .

34 EPP, supra note 25, at 197-205.

${ }^{35}$ See Susan Olson, Interest Group Litigation in Federal District Court: Beyond the Political Disadvantage Theory, 52 J. PoL. 854 (1990).

${ }^{36}$ See generally Marc Galanter, Whythe Haves Come Out Ahead: Speculations on the Limits of Legal Change, 9 L. \& SoC'Y. REV. 95 (1974) [hereinafter Galanter, Why the Haves]; Peter McCormick, Party Capability Theory and Appellate Success in the Supreme Court of Canada, 1949-1992, 26 CANADIAN J. POL. SCI. 523 (1993); Donald R. Songer \& Reginald S. Sheehan, Who Wins on Appeal? Upperdogs and Underdogs in the United States Courts of Appeals, 36 AM. J. POL. SCI. 235 (1992); Stanton Wheeler et al., Do the "Haves" Come Out Ahead? Winning and Losing in State Supreme Courts, 1870-1970, 21 L. \& SoC'Y REV. 403 (1987); Yoav Dotan, Do the 'Haves' Still Come Out Ahead? Resource Inequalities in Ideological Courts, 33 L. \& Soc'Y REV. 1059, 1063-64 (1998) [hereinafter, Dotan, Do the "Haves" Come Out Ahead?].

${ }^{37}$ See generally Ashlyn K. Kuersten et al., Reexamining When and Where the Haves Come Out Ahead: The Intersection of Party Capability Theory and Political Disadvantage Theory in State Supreme Courts, Paper presented at the annual meeting of the Midwest Political Science Association (Chicago, 111. 1998); Stacia L. Haynie, Resource Inequalities and Litigation Outcomes in the Philippine Supreme Court, 56 J. POL. 752 (1994); Susan Brodie Haire et al., Attorney Expertise, Litigant Success, and Judicial Decisionmaking in the U.S. Court of Appeals, 33 L. \& SOC'Y REV. 667 (1999). 
skills to those who otherwise would be resource poor"38 (for example, networking, finding and disseminating information, raising money, and public communication), especially (but not limited to) the United States, which lacks strong political parties and labor unions.

Social movement theory adds another dimension to the relationship between resources and the development of rights-advocacy organizations. Resource mobilization versions of social movement theory stress that incipient movements can rarely sustain momentum without mobilizing resources and organizing members into some kind of formal arrangement. ${ }^{39}$ Drawing from this theory, studies of rights-advocacy movements have detailed the important role of organizational resources at different stages of legal mobilization. ${ }^{40}$ Developing an organizational apparatus supports and prolongs a rightsadvocacy movement in various ways. Organizations are able to gather intelligence and store information, publicize and establish long-term credibility with constituents and elites, coordinate activities in different legal and political forums, and develop legal expertise beyond the capacities of individual attorneys.

By mobilizing these resources, organizations in any national setting can become repeat players; unlike many parties to litigation, they can absorb immediate losses with relative ease, focusing instead on building favorable rules over the long term through the ebb and flow of successive litigation. ${ }^{41}$ The organization can also provide a show of unity and collective intensity that has influence in the legislative environment. In sum, a plausible explanation for legal mobilization in the U.S., India, and Israel is a combination of the necessity of developing resources for mobilization, the availability of these resources in religious institutions, and the benefits of organizational structure.

\section{Political Disadvantage and Other Institutional Considerations}

Formal political institutions outside of the courts-the legislative, executive, and administrative - can shape the legal mobilization of organized

${ }^{38}$ SIDNEY Verba ET AL., VOICE AND EQUALITY: CIVIC VOLUNTARISM IN AMERICAN POLITICS 330 (1995).

${ }^{39}$ See generally Uther Gerlach \& VIRgINIA Hines, People, POWER, AND Change: MOVEMENTS AND SOCIAL TRANSFORMATION (1970); John McCarthy \& Mayer Zald, Resource Mobilization and Social Movements: A Partial Theory, 82 AM. J. Soc. 1212 (1977).

${ }^{40}$ See, e.g., MiCHAEL MCCANN, RIGHTS AT WORK: PAY EQUITY REFORM AND THE POLITICS OF LEGAL MOBILIZATION (1994); JOEL HANDLER, SOCIAL MOVEMENTS AND THE LEGAL SYSTEM: A THEORY OF LAW REFORM AND SOCIAL CHANGE (1978).

${ }^{41}$ See Galanter, Why the Haves, supra note 36. 
groups in various ways. Perhaps the most prominent scholarly explanation of the relationship between these non-judicial institutions and legal mobilization is that individuals or organized groups are apt to use legal advocacy, and particularly litigation, only when they have exhausted other political options. This "political disadvantage" hypothesis holds that groups are unlikely to litigate unless they perceive themselves at a disadvantage in other political institutions. ${ }^{42}$ The idea of disadvantage was particularly salient as the U.S. Supreme Court began to judge the rights-claims of minority groups during the Civil Rights era, prompting the Court itself to suggest that, "under the conditions of modern government, litigation may be the sole practicable avenue open to a minority to petition for redress of grievances." 43 The NAACP's efforts to use political litigation to end racial discrimination, as well as the use of courts by women's groups and certain religious minorities, are well-documented case studies of the role of political disadvantage in legal mobilization. ${ }^{44}$

As a general theory of organized legal advocacy, however, the focus on political disadvantage has clear shortcomings. ${ }^{45}$ For example, it does not explain the behavior of groups that use litigation as part of a comprehensive strategy that includes advocacy within legislative and/or administrative arenas. ${ }^{46}$ If groups were disadvantaged in these arenas, the political disadvantage theory would not predict such a strategy. We are also skeptical of this theory because some minority groups that are disadvantaged in other political arenas play only a minimal role in legal advocacy, perhaps because, as one sees in many countries outside of the United States, courts are not as easily accessible to groups (though, as we describe later, group accessibility to courts is relatively open in Israel and India). The message of these kinds of objections is that the disadvantage theory is time-and nation-bound to the civil rights era in the U.S. and too narrowly focused to help explain the range of interest group participation in litigation. As courts have become sites for

${ }^{42}$ See Richard Cortner, Strategies and Tactics of Litigants in Constitutional Cases, $17 \mathrm{~J}$. PUB. L. 287 (1968).

${ }^{43}$ NAACP v. Button, 371 U.S. 415, 430 (1963).

44 See generally Clement Vose, Caucasians ONLy (1959); MARK TUSHNET, THE NAACP's LEGAL STRATEGY AGAINST SEGREGATED EDUCATION, 1925-1950 (1987); RICHARD KLUGER, SIMPLE JUSTICE (1975); MCCANN, supra note 40; KAREN O'CONNOR, WOMEN'S ORGANIZATIONS USE OF COURTS (1980).

45 See generally Olson, supra note 35; LeE EPSTEN, CONSERVATIVES IN COURT (1985); Scheppele \& Walker, supra note 9.

${ }^{46}$ See Stephen Wasby, Litigation and Lobbying as Complementary Strategies in Civil Rights, in LEGACIES OF THE 1964 CIVIL RIGHTS ACT 65, 70-71 (Bernard Grofman ed., 2000). 
greater organized conflict in recent decades, groups at all levels of political clout have turned to litigation to advance their policy goals by claiming or denying legal rights.

The problems with the political disadvantage theory, however, should not imply that executive and legislative institutions have no affect on legal mobilization. In fact, governmental institutions that support a group's policy goals can shape legal mobilization in significant ways. For example, the interplay of government agencies and litigating groups can foster a division of labor that influences the actions of both sides. ${ }^{47}$ This division of labor is usually not a matter of purposeful coordination, but rather, "an interest group, seeing where government places its effort, invests its resources elsewhere." ${ }^{38}$ In other instances, the cooperation between government and organized groups may be more deliberate, ranging from sharing basic information to serving as co-counsel in a case. Moreover, a government institution that supports a group's policy goals may nevertheless fail to cultivate a supportive environment for groups to advance those goals. The entry of government attorneys into a case, as Wasby notes, "complicates the work of interest group litigators while the government's presence constrains group control of litigation." 49

\section{An Alternative Consideration: Ideas}

The contextual and resource-centered explanations move us some distance toward explaining religious group legal advocacy. As we shall see, legal mobilization requires attention to all of these factors. But these arguments focus mainly on how groups respond to what they have (or do not have), not on what members of groups believe (or do not believe) about the nature and legitimacy of law and politics themselves. This becomes an important omission when we recognize that worldviews-sets of ideas that help groups explain, evaluate, and engage the social and political world-may either encourage or close off legal advocacy regardless of a group's political context or resources.

The recent "cultural turn" in social movement studies suggests that these orientations are decisively important in understanding group behavior, ${ }^{50}$ and several studies have suggested that religious convictions explain religious

${ }^{47}$ See WASBY, supra note 32 , at 21.

48 Id.

49 Id. at 22.

so See generally Stephen Hart, The Cultural Dimension of Social Movements, 57 Soc. of RELIGION 87 (1996). 
interest group activities in particular. ${ }^{51}$ Nevertheless, group ideas about law and politics are absent from many studies of rights-advocacy groups. Even studies devoted to conservative group litigation do not take into account the ideological commitments that define these groups, relying instead on institutional and resource-centered explanations. ${ }^{52}$

In most of these studies, group ideas are simply taken for granted or assumed out of a decision-calculus that primarily involves strategic consideration of contextual or resource factors. Our project does not proceed with that assumption, but argues that the choice to use one legal tactic over another, let alone to use legal advocacy at all, may have as much to do with frameworks of ideas or "worldviews" as expectations about the actions of other legal actors or access to money and expertise. Drawing from several theoretical frameworks, ${ }^{53}$ we use the term "ideas" to distinguish a particular set of beliefs that motivates action. These beliefs are embedded in worldviews, relatively coherent and comprehensive frameworks of belief that individuals use to explain, evaluate, and ultimately engage the social and political world around them. The dual metaphors of "map" and "lens" help describe a worldview: like a cognitive map, it directs and channels adherents in certain directions; like a lens, it clarifies or magnifies certain experiences and concerns over others.

Worldviews include both causal and normative ideas. Causal ideas are explanatory: they specify the cause-effect relationships that make sense of complex events and conditions. Normative ideas are evaluative and relational: they supply standards for distinguishing right from wrong and just from unjust and they prescribe how people should treat each other, thereby evoking deep emotions and loyalties. Religious groups, which are relatively upfront about their defining beliefs, are valuable case studies of the role of worldview in legal and political behavior. Adherents to religious worldviews, for example,

51 See ALlEN HERTZKE, REPRESENTING GOD IN WASHINGTON (1988); DANIEL HoFrENNING, IN WashIngton BUt Not OF IT: The PROPHETIC POLITICS Of RELIGIOUS LOBBYISTS (1995); Ronald Pagnucco, A Comparison of the Political Behavior of Faith-Based and Secular Peace Groups, in DISRUPTIVE RELIGION: THE FORCE OF FAITH IN SOCIAL MOVEMENT ACTIVISM (Christian Smith ed., 1996).

s2 See, e.g., EPSTEN, supra note 45.

53 Some of these theoretical concepts have been developed in subject areas ranging from international relations to American public policy. See, e.g., Judith Goldstein \& Robert O. Keohane, Ideas and Foreign Policy: An Analytical Framework, in IDEAS AND FOREIGN POLICY: BELIEFS, INSTITUTIONS, AND POLITICAL CHANGE (Judith Goldstein \& Robert O. Keohane eds., 1993); John Kingdon, Agendas, Ideas, and Policy Change, in NEW PERSPECTIVESON AMERICAN Politics (Lawrence Dodd \& Calvin Jilson eds., 1994); PETER HALL, THE POLITICAL POWER OF ECONOMIC IDEAS: KEYNESIANISM ACROSS NATIONS (1989). 
often (though not always) posit the causal idea that God or another supernatural force determines a particular course of events through direct intervention in human affairs (e.g., "providence," "karma"). These interventions (or expectations of these interventions) may themselves require religionists to take certain ritualistic normative actions (e.g., prayer, vows of poverty, acceptance of behavioral codes) out of obedience or some other sense of obligation. These include social and political obligations that are preconditions of legal claims. ${ }^{54}$

\section{RELIGION AND LITIGATION IN THE UNITED STATES: TWO RELIGIOUS TRADITIONS}

It would be impossible to survey the remarkable diversity of religious interest group litigation in the United States within the confines of this study. ${ }^{55}$ As illustrations, we examine specific groups associated with two religious traditions that have mobilized law during the past three decades: Roman Catholicism and conservative evangelical Protestantism. To tighten the focus further, we concentrate on their efforts before the Supreme Court from 1971$2000,{ }^{56}$ and we examine two policy areas of particular concern to both

54 For a further discussion of this subject, see CAROL GREenhouse, PRAYING fOR JUSTICE (1986); JEROLD S. AUERBACH, JUSTICE WITHOUT LAW? RESOlVING DISPUTES WithOUT LAWYERS (1983).

ss Most treatments of religious group litigation have focused on particular groups (e.g. Jews, Jehovah's Witnesses) and/or specific areas of law (e.g. church-state, free speech, right to privacy. See, e.g., IVERS, TO BUILD A WALL, supra note 5; Ivers, Please God, supra note 2; KOSHNER, supra note 2; CAROLYN N. LONG, RELIGIOUS FREEDOM AND INDIAN RIGHTS: THE CASE OF OREGON V. SMITH (2000); SHAWN FRANCIS PETERS, JUDGING JEHOVAH'S WITNESSES: RELIGIOUS PERSECUTION AND THE DAWN OF THE RIGHTS REVOLUTION (2000); SORAUF, supra note 2.

s6 1971 is a good point of departure because it barely predates the mid-1970s emergence of conservative evangelicals into the political realm. See generally KENNETH WALD, RELIGIONAND POLITICS IN THE UNITED STATES 218-25 (3d ed. 1997). The U.S. Supreme Court also decided three landmark cases pertaining to education and abortion in the early 1970s: Lemon v. Kurtzman, 403 U.S. 602 (1971) (holding that a program of state aid to church-affiliated elementary and secondary schools violates the Establishment Clause); Tilton v. Richardson, 403 U.S. 672 (1971) (arguing unsuccessfully that providing state funds for building construction at religious colleges violates the Establishment Clause); and Roe v. Wade, 410 U.S. 113 (1973) (holding that the constitutional right to privacy protects a woman's qualified right to an abortion procedure). Of course, the Supreme Court is not the only venue for legal mobilization. For a discussion of evangelical efforts to litigate at the lower federal court level, see also Steven P. Brown, The Pornography of the 1990s? Religion, Free Speech, and the New Christian Right in the Courts, (Paper Presented at the Annual Meeting of the Midwest Political Science Association, 1998) (on file with authors). 
traditions: abortion and education.

\section{A. The Rise in Legal Advocacy Within the Evangelical Protestant Movement}

With the exception of some sporadic litigation activity, evangelical Protestants expended relatively little systematic effort to engage the courts as case sponsors or amicus curiae throughout the 1970 s and well into the 1980 s. $^{57}$ Legal activism began to increase as evangelicals began to move to a posture of broader public engagement. Indeed, at least half of the Supreme Court cases addressing abortion, right-to-die, or education since 1989 included evangelical sponsorship and all of them have included amicus briefs by evangelical organizations. ${ }^{58}$ The American Center for Law and Justice (ACLJ), headed by Jay Alan Sekulow, has been among the most active advocacy groups, litigating a string of controversial cases addressing the free speech rights of abortion protesters ${ }^{59}$ and various church-state matters. ${ }^{60}$ Since 1994, the Alliance Defense Fund (ADF) has begun to rival the ACLJ as an evangelical influence on the flow of cases through the appellate courts. However, the ADF does so with a unique behind-the-scenes strategy by making financial grants to other organizations to fund their efforts to litigate religious freedom and sanctity-of-life cases. ${ }^{61}$ From the mid-1980s to the

57 In 1981, attorneys for the Center for Law and Religious Freedom at the Christian Legal Society had aided the litigants in Widmar v. Vincent, 454 U.S. 263 (1981) (arguing that access to state university facilities by registered student groups does not violate the separation of church and state). In 1985, Michael Farris, then counsel for Concerned Women for America, argued on behalf of petitioners in Witters v. Washington Department of Services for the Blind, 474 U.S. 481 (1986) (addressing the right of blind students to use public assistance to pay the educational costs of a Christian college).

s8 These figures were derived by identifying evangelical group participation in thirty-five right to privacy cases and thirty-five education-related cases from 1971-2000. U.S. REPORTS, BRIEFS AND RECORDS OF THE U.S. SUPREME COURT, and the Lexis database contain the relevant data on both case sponsorship (identified as an evangelical group's attorney appearing on a primary brief for the case) and amicus participation. For a thorough discussion, see DEN DULK, supra note 2, at 23-24, 42-52.

59 Bray v. Alexandria Women's Health Clinic, 506 U.S. 263 (1993); National Org. for Women v. Scheidler, 510 U.S. 249 (1994); Schenck v. ProChoice Network, 519 U.S. 357 (1997); Hill v. Colorado, 530 U.S. 703 (2000).

${ }^{60}$ Lee v. Weisman, 505 U.S. 577 (1992); Sante Fe Indep. Sch. Dist. v. Doe, 530 U.S. 290 (2000) (both holding that prayers offered at school functions violate the Establishment Clause); Lamb's Chapel v. Center Moriches Union Free School District, 508 U.S. 384 (1993) (holding that religious groups not associated with a public school have a right to the same access to school facilities as any other group).

${ }^{61}$ ADF was the financial muscle, for example, behind the landmark case, Rosenberger $v$. Rector and Visitors of Univ. of Va., 515 U.S. 819 (1995) (holding that using state funds to 
present, amicus curiae filings have also become a staple of evangelicals in education and abortion/right-to-die cases, but evangelicals were absent from such cases in the 1970s. Only one amicus brief was filed by an evangelical organization among the total of 166 briefs sent to the Court between 1971 and $1980 .^{62}$ From $1981-90$, evangelicals filed forty-nine, or approximately $14 \%$, of the 350 briefs filed. ${ }^{63}$ From 1991-2000, evangelicals accounted for 77 out of 384 filings, or $20 \%$ of the briefs for the period, with a peak of $27 \%$ from $1991-95 .^{64}$

What accounts for these trends in political litigation among evangelical Protestants? The political environment and the availability of resources have factored in the development of evangelical rights advocacy over these decades. Concerns about judicial rulings, support from legislatures and other public officials during the Reagan and Bush administrations, organizational structure, the leadership of Sekulow and other media savvy lawyers, the Alliance Defense Fund's model of organizational maintenance-all of these factors had varying roles to play in the mobilization of rights-advocacy groups associated with evangelical Protestantism. ${ }^{65}$ Yet, taken together, these factors neglect another variable that catalyzed the evangelical movement: religious ideas.

It was not until intellectuals and other elites within the broader world of evangelicalism became convinced that "secular forces" must be confronted in terms of a theology of activist politics that evangelical rights-advocacy groups began to form in the mid-1970s. This argument is consistent with other studies of legal mobilization that reveal the importance of elites in publicizing grievances and opportunities for redress. ${ }^{66}$ As evangelical leaders began to nudge their fellow religionists out of apolitical isolation, a small group of evangelical attorneys began to see lawyering as a distinctively religious vocation.

By 1980 , for example, editorialists at Christianity Today $(C T)$, the most prominent evangelical magazine at the time, admitted a "radical 180-degree

publish a student religious newspaper at a public university is protected under the First Amendment).

${ }_{62}$ These statistics were derived in two stages: (1) dividing the number of amicus briefs in a specific time period into the total number of briefs filed by all individuals and groups, and (2) computing the proportion of these briefs with evangelical participation. See DEN DULK, supra note 2 , at 51-52.

${ }^{63}$ See id.

ot See id.

${ }^{65}$ See Ivers, Please God, supra note 2; DEN DULK, supra note 2.

66 See, e.g., MCCANN, supra note 40; STUART SCHEINGOLD, THE POLITICS OF RIGHTS (1974). 
reversal" of their earlier opposition to tax support for Christian colleges. ${ }^{67}$ The trigger was the magazine's belief that public universities were no longer neutral institutions, but rather homes for a "religion of secular humanism" that place human beings rather than God at the center of the moral and legal universe. ${ }^{68} C T$ also saw the secular humanists hard at work in the abortion battles, "profaning" religious convictions by claiming that human choice trumps the will of God. ${ }^{69}$ Leaders at $C T$ began to view evangelicalism's lack of active resistance to abortion as an affront to the "sacredness"70 and "dignity" "apathetic" 72 and "self-absorbed," raising some unappealing comparisons. "Christians no longer need to puzzle about the absent witness of the church in Nazi Germany," a CT editorialist wrote in 1979..$^{74}$ "Unless there is a Christian outcry against man's diminished dignity, history may once again repeat itself."

Meanwhile, other evangelical opinion leaders and activists were raising the specter of abortion and issuing even more explicit calls for Christian cultural (and particularly legal) engagement. Francis Schaeffer, an American pastor and writer who operated L'Abri Fellowship in Switzerland as a ministry to young evangelical intellectuals, provided a particularly strong bridge between ideas and action. He authored widely read books and produced, wrote, and narrated several popular film series that identified the $R o e^{76}$ decision as a culmination of the steady movement of American constitutionalism away from its traditional bedrock in biblical principles and toward a foundation in the arbitrariness of secular humanism. ${ }^{77}$ To combat these trends, Schaeffer struck

${ }^{67}$ Tax Support for Christian Colleges: Balancing the Ledger, CHRISTIANITY TODAY, Nov. 7,1980 at $10-11$.

${ }^{68}$ See id.

${ }^{69}$ See Beyond Personal Piety, Christianity Today, Nov. 16, 1979, at 13.

70 See id.

$"$ See id.

${ }^{2} I d$.

${ }^{73} \mathrm{Id}$.

${ }^{74} \mathrm{Id}$.

75 See Beyond Personal Piety, supra note 69, at 13.

${ }^{76}$ See Roe v. Wade, 410 U.S. 113 (1973).

77 See generally Francis A. SCHAEFFER, How SHOULd WE THEN LIVE? THE RISE AND DECLINE OF WESTERN THOUGHT AND CULTURE (F.H. Revell 1976) [hereinafter SCHAEFFER, HOW SHOULD WE THEN LIVE?]; see also FRANCIS A. SCHAEFFER, WHATEVER HAPPENED TO THE HUMAN RACE? (1979) [hereinafter SCHAEFFER, WHATEVER HAPPENED]; see also FRANCIS A. SCHAEFFER, A CHRISTIANMANIFESTO (1982) [hereinafter SCHAEFFER, CHRISTIANMANIFESTO]. 
directly at the heart of evangelical apathy in the legal arena, chiding the attorneys in his audience for ignoring the dramatic change in recent decades:

Where were the Christian lawyers during the crucial shift from forty years ago to just a few years ago? Surely the Christian lawyers should have seen the change taking place and stood on the wall and blown the trumpets loud and clear. A nonlawyer like myself has a right to feel somewhat let down because the Christian lawyers did not blow the trumpets clearly between, let us say, 1940 and $1970 .^{78}$

The role of religious opinion leaders and activists was built into the development of evangelical law firms in the 1980 s and early 1990 s. $^{79}$ Some evangelical attorneys, like John Whitehead, founder of the Rutherford Institute in 1982, fell under the tutelage of evangelical pastors and intellectuals. ${ }^{80}$ Many others sought guidance from evangelical colleagues in the legal profession. The Christian Legal Society, a fellowship of largely evangelical attorneys, institutionalized a unique combination of professional and spiritual mentorship and helped channel some of its members into church-state law through its own firm, the Center for Law and Religious Freedom (CLRF), founded in 1975. ${ }^{81}$ Numerous interviewees traced their first experiences with answering a call to law as a religious vocation to the Christian Legal Society. ${ }^{82}$ The organization facilitated the recognition of distinctly religious obligations, providing "integration into [a] supportive network that acts as a structural 'pull" encouraging the individual to make good on his or her strongly held beliefs," as Douglas McAdams, a scholar of social movements, describes the role of such organizations.

78 SCHAEFFER, CHRISTIAN MANIFESTO, supra note 77, at 47.

79 DEN DULK, supra note 2.

${ }^{80}$ For example, Whitehead's choice of Samuel Rutherford, the seventeenth-century Scottish theologian, as the namesake of the Institute was an obvious paean to Schaeffer, who saw Rutherford as the primary authority on the proper meaning of the rule of law.

${ }^{81}$ See generally Christian Legal Society Webpage at http://www.christianlegalsociety.org (last visited Feb. 19, 2002).

${ }^{82}$ Second author interview with Steven McFarland, Counsel for CLRF (last July 22, 1999); Second author interview with Samuel Ericsson, Counsel for Advocates International (last July 2, 1999); Second author interview with Bradley Jacobs, Counsel for Home School Legal Defense Association (July 27, 1999); Second author interview with Gregory Baylor, Counsel for CLRF (July 22, 1999).

${ }^{83}$ Douglas McAdam, Recruitment to High Risk Activism: The Case of Freedom Summer, 92 AM. J. SoC. 64 (1986). 
By the early 1980 s the CLRF, Rutherford, and several other firms had been created to answer such a call to litigation, and the American Center for Law and Justice and Alliance Defense Fund would soon follow in 1990 and 1994, respectively. ${ }^{84}$ The call to litigation was not undifferentiated; legal advocacy took many different forms. Some of the earliest advocacy was designed largely to defend the evangelical subculture (e.g. protecting the institutional autonomy of private religious schools), but over time groups became increasingly concerned with what they perceived as the secularization and moral decay of the broader culture, as evidenced in greater mobilization in opposition to abortion rights. Some firms mobilized to protect abortion protestors against considerable opposition; ${ }^{85}$ other groups such as Legal Action for Women and Life Dynamics facilitated malpractice lawsuits against abortion providers; still others focused on incremental policy-oriented litigation (e.g. bans on late term abortion, restrictions on stem cell research, parental and spousal notification) ${ }^{86}$ Whatever the form of legal advocacy, however, evangelical political litigation was motivated in part by a set of changing evangelical ideas about both substantive policy areas and public engagement in general.

\section{B. Legal Advocacy Within the Roman Catholic Movement}

While many Catholics shared evangelical concerns such as moral decay, the ascendancy of secular humanism, desire for more public accommodation of religious education, opposition to abortion rights, they did not generally follow the same trends in legal mobilization. Roman Catholics, whether through the Church's substantial institutional apparatus or myriad lay organizations, had been active legal advocates for many decades. ${ }^{87}$ The

84 See generally AMERICANCENTER FOR LAw \& JUSTICE, at http://www.aclj.org (last visited Mar. 7, 2002); see also ALLIANCE DEFENSE FUND http://www.alliancedefensefund.org (last visited Mar. 7, 2002).

${ }^{85}$ See generally Robert Van Dyk, The Pro-Choice Legal Mobilization and Decline of Clinic Blockades, in Leveraging the LAW: UsING the COURTS to ACHIEVE SOCIAL ChaNGe 135 (D.A. Schultz ed., 1998).

${ }^{86}$ There are numerous works describing the strategies and tactics of abortion rights foes in the United States. See generally BARBARA HINKSON CraIG \& DAVID M. O'BRIEN, ABORTION AND AMERICAN POLITICS (1993) and KAREN O'CONNOR, NO NEUTRAL GROUND? ABORTION POLITICS IN AN AGE OF ABSOLUTES (1996).

${ }^{87}$ Much of the earliest advocacy addressing church-state conflicts arose from the role and public support of Catholic schools. Catholics were placed repeatedly in a defensive position in state courts, and began to take their cases to federal courts, including the U.S. Supreme Court, at least as early as 1908. See, e.g., Quick Bear v. Leupp, 210 U.S. 50 (1908) (upholding the disbursement of federal funds to Catholic missions schools that offered instruction to Native 
difference between this advocacy and evangelical legal activity was that Catholic organizations had maintained a relatively constant rate of participation. Though the legal mobilization of evangelical groups increased disproportionately compared to other groups from 1970 to 2000, Catholic organizations maintained consistent amicus participation (between 7 and $14 \%$ of total filings in education and abortion cases combined) and case sponsorship across time. ${ }^{88}$

Again, differing ideas explain this variation between the two religious traditions. For over two millennia, the Catholic Church has developed a rich body of social teaching and justifications for engagement in public life and intellectual traditions that evangelicals simply lack. This is not to say that the Catholic Church's considerable institutional resources played little role in its legal advocacy, but rather that the Church would be less likely to mobilize those resources without notions of "common good," "natural law," and "social justice" that enable public engagement.

A key catalyst for translating these ideas into action in recent decades was the Second Vatican Council (or "Vatican II"), a remarkable gathering of Roman Catholic bishops from around the world. ${ }^{89}$ Pope John XII initiated the Council, which lasted from 1962 to 1965 , as a call to renewal in various areas of church life and as a response to profound social and political changes in the wake of World War II..$^{90}$ Vatican II's message and its impact remain intensely controversial, but many of its declarations had relatively clear implications for how the American Catholic Church would view law, politics, and society in subsequent decades. ${ }^{91}$ It is therefore useful to examine how the American bishops appropriated salient messages from Vatican II and applied them to the legal environment in the United States.

Americans) Pierce v. Society of Sisters, 268 U.S. 510 (1925) (affirming an order, obtained by a Roman Catholic school, that barred enforcement of a popular initiative in Oregon requiring all parents to send their children to public schools between the ages of eight and sixteen). For a detailed discussion of Catholic legal advocacy from the Civil War to the Great Depression, see DEN DULK, supra note 2, at 218-23.

${ }^{88}$ These statistics were derived using the same procedure as used with respect to evangelical participation. See supra note 58.

${ }^{89}$ For reflections on the role of U.S. Catholics in the Second Vatican Council, see generally VINCENT YZERMans, AmERICAN PARTICIPATION IN THE SECOND VATICAN COUNCIL (1967).

${ }^{0}$ The statements generated by the gathering can be found in VATICAN COUNCIL II: CONCILIAR AND POST CONCILIAR DOCUMENTS (Austin Flannery ed., 1996).

${ }^{1}$ See generally TIMOTHY BYRNES, CATHOLIC BISHOPS IN AMERICAN POLITICS (1991); JOHN T. Ellis, AMERICAN CATHOlicism (1969); JAMES HeNNESEY, S.J., AMERICAN CATHOLICS: A HISTORY OF THE ROMAN CATHOLIC COMMUNITY IN THE UNITED STATES (1981). 
The conciliar document most relevant to Catholic legal mobilization was the Declaration of Religious Liberty, which Vatican II adopted in $1965 .^{92}$ While reaffirming the "traditional Catholic teaching on the moral duty of individuals and societies toward the true religion and the one Church of Christ,"93 the Declaration argued that all individuals, Catholic or not, have a fundamental human right to religious freedom. By explicitly acknowledging religious freedom, the Church recognized social pluralism and the legitimacy of the secular state, a dramatic change from the Vatican's earlier positions. For example, partly in response to the so-called "Americanist" heresy among post-Civil War prelates, Pope Leo XII had issued Longinqua Oceani in 1895 and Testem Benevolentiae in 1899, both of which condemned what he perceived as some American bishops' adaptation to modernity and liberal democracy. Leo commented:

It would be erroneous to draw the conclusion that in America is to be sought the type of the most desirable status of the Church, or that it would be universally lawful or expedient for State and Church to be, as in America, dissevered and divorced. . . . but she [the Church] would bring forth more abundant fruits if, in addition to liberty, she enjoyed the favor of the law and patronage of public authority. ${ }^{94}$

By rejecting "religious Americanism," Leo was "expressing the fear that accommodation of the Church to democracy as a form of government might entail the introduction of democracy into the Church itself." 95 In contrast, through the Declaration, Vatican II recognized the link between democratic governance and some church-state separation as consistent with the Church's own theological emphasis on goods common to Catholics and non-Catholics alike. $^{96}$

It is not surprising that the American bishops and the leading American Catholic public theologian of the time, John Courtney Murray, were the strongest champions of the document at the Council. The Catholic experience of nativism in nineteenth century America had taught them the "practical

92 Vatican Council II, Declaration of Religious Liberty, in VATICANCOUNCIL II: CONCILIAR AND POST CONCILIAR DOCUMENTS, supra note 90.

${ }^{93}$ Id.

94 Pope Leo XIII, Longinqua Oceani, in 2 DOCUMENTS OF AMERICAN CATHOLIC HISTORY 502 (J.T. Ellis ed., 1987).

95 RICHARDP. MCBRIEN, CAESAR's CONN: RELIGION AND POLITICS IN AMERICA 116 (1987).

${ }^{96}$ See Vatican Council II, supra note 92. 
value" of making such a declaration, as Murray put it. ${ }^{97}$ But Murray had also come to believe that Catholic public theology, with its emphasis on using law to promote the common good, implied widespread religious freedom. Hence, he argued that the "American schema," as the Declaration came to be called, was compatible with American public values, particularly the First Amendment's protection of religious exercise from governmental intrusion. ${ }^{98}$ The Religion Clauses of the First Amendment, Murray argued in his landmark book, We Hold These Truths (1960), are not theological propositions but practical attempts to prevent violence and social disunity. ${ }^{99}$ These "articles of peace" ${ }^{100}$ fit with Catholic social teaching, which treats social peace as a "high moral value" $10 !$ that is part of the common good.

Other conciliar documents complemented the Declaration's message about church and state. The Pastoral Constitution of the Church in the Modern World challenged the bishops to engage "the whole of humanity" 102 rather than insulating the Church from the broader culture. As a result, in areas of family life, war, and economic relations, the document "authorized the American bishops to turn their attention to the whole range of social problems facing the American people." ${ }^{103}$ The Pastoral Constitution, for example, rejected abortion and euthanasia in the strongest terms, ${ }^{104}$ and soon both issues would become top agenda items for the American hierarchy. The document also raised questions about modern warfare and economics, two issue areas that were analyzed in detail by the American bishops in the 1970s and 1980s. ${ }^{105}$

In the Dogmatic Constitution on the Church, Vatican II also strengthened the authority of the bishops relative to the papacy. The question of authority is, of course, crucially important in the history of the Roman Catholic

97 See John Courtney Murray, S.J., Commentary on the Declaration of Religious Freedom, in AMERICAN PARTICIPATION DN THE SECOND VATICAN COUNCIL 668 (V. Yzermans ed., 1967).

98 See id.

99 See generally JOHN COURTNEY MURRAY, WE HOLd ThESE TRUTHS: Catholic REFLECTIONS ON THE AMERICAN PROPOSITION 56 (1960).

${ }^{100}$ Id. at 56.

101 Id. at 60.

102 Vatican Council II, Pastoral Constitution of the Church in the Modern World, in VATICAN COUNCIL II: CONCILIAR AND POST CONCILIAR DOCUMENTS, supra note 90, at 903-1001 [hereinafter Pastoral Constitution].

${ }^{103}$ BYRNES, supra note 91 , at 40.

104 See Pastoral Constitution, supra note 102.

los See, e.g., The Challenge of Peace: God's Promise and Our Response, in PASTORAL LetTERS OF THE UNited STATE CaTHOLIC Bishops, Vol. IV, 493-581 (Hugh J. Nolan ed., 1984); Economic Justice for All, in Pastoral Letters of the UNTEd States Catholic BiSHOPS, Vol. IV, 371-492, Vol. V (Hugh Nolan ed., 1984). 
Church. ${ }^{106}$ To appreciate its role in modern Church governance, one must go back to the First Vatican Council, which convened from 1869-70. Vatican I had asserted that every pope has full and supreme teaching power in the Church, including the prerogative of infallibility, whereby the pope is presumed free from error in promulgating Church doctrine regarding faith and morals. ${ }^{107}$ In contrast, Vatican Irs Dogmatic Constitution reinforced another doctrine, often called "collegiality," which states that the authority of the bishops as a group derives directly from God, not by delegation from the pope. In other words, the Dogmatic Constitution instructed bishops to understand themselves not as the pope's lieutenants, but as members of a larger body that collectively exercises ultimate authority in the Church. In a related statement, the Decree on the Pastoral Office of Bishops in the Church exhorted the bishops to work more closely with other members of the episcopate in their respective countries. ${ }^{108}$ In 1966 after Vatican II but in the spirit of both the Dogmatic Constitution and the Decree on the Pastoral Office of Bishops, the U.S. bishops moved from a loose confederation to create the National Conference of Catholic Bishops (NCCB), which they headquartered in Washington, D.C. ${ }^{109}$ The NCCB also established the U.S. Catholic Conference (USCC) as its administrative and public policy arm. Unlike the loose confederation, which had focused on defending institutional interests like education, ${ }^{110}$ the USCC tackled a broad range of controversial issues; it was the organizational vehicle for fulfilling the Pastoral Constitution's prescriptions. ${ }^{11}$

These key documents-the Declaration of Religious Liberty, Pastoral Constitution, Dogmatic Constitution, and Decree on the Bishop's Pastoral Office of Bishops-created broad frameworks of thought and practice for the global Church. It is important to note, however, that Vatican II was not a meeting about specific tactics of public engagement. Consequently, the link from Vatican II ideas to Catholic rights advocacy is not straightforward.

106 Vatican Council II, Dogmatic Constitution on the Church, in VATICAN COUNCIL II: CONCILIAR \& POST CONCILIAR DOCUMENTS, supra note 90.

107 The Council's decree on the authority of the Pope can be found at FIRST VATICAN ECUMENICAL COUNCLL, DOGMATIC CANONS AND DECREES: AUTHORIZED TRANSLATIONOF THE DOGMATIC DECREES OF THE COUNCIL OF TRENT, THE DECREE ON THE IMMACULATE CONCEPTION, THE SYLLABUS OF POP PIVIS IX, AND THE DECREES OF THE VATICAN COUNCIL (1977).

108 Vatican Council II, Decree on the Pastoral Office of Bishops in the Church, in VATICAN COUNCIL II: CONCILIAR AND POST CONCILIAR DOCUMENTS, supra note 90.

${ }^{109}$ For a brief history of this change and its political implications, see BYRNES, supra note 91.

"10 See generally. LUKE E. EBERSOLE, ChURCH LOBBYING IN THE NATION's CAPITOL (1951).
'11 See generally BYRNES, supra note 91 . 
However, the Council provided a set of ideas-explanatory and evaluative beliefs about the role of the Church in public life-that would provide a basis for the USCC and other Catholic groups to mobilize the law.

Some of these ideas were translated into a strong sense of partnership with the state. Mark Chopko, the USCC's current General Counsel, describes Vatican II's practical influence as enabling Church agencies to search out ways they could work with government to advance the common good. ${ }^{112}$ As he stated:

How Catholics post-Vatican II would approach [legal advocacy] is to say that we have certain interests and the government has certain interests and many of these interests overlap. We don't want to be in the business of government just as we don't want government to be in the religion business. But there are things that we share in common-education, elderly, care for the poor, and so on-that we do out of religious motivations, they do out of a social welfare obligation. And the practical question is, "How do we make this work? How do we cooperate together for the common good of society?" Whether you come at it for a religious motivation or a social welfare motivation or none of the above we need to find a way to work with each other. ${ }^{113}$

Yet the USCC's legal department is not naive about the risks in such a partnership. Chopko's statement is tempered by both wariness of governmental power and an acknowledgment of occasional accommodation to state demands.

We know that when we work in an area in which the government has an interest, there's going to be tension and there's going to be some overlap. ... O Other churches tend to draw the religious circle more broadly than we do. We recognize that to live in this society you've got to make certain kinds of accommodations. ... Other churches are saying, "If we can't do it, maybe we shouldn't be in this." Well, that's their choice. But that's not the choice we've made as part of our self-understanding of who we are in this community-the

112 Second author interview with Mark Chopko General Counsel, USCC (July 15, 1999). 113 Id. 
United States-and how we define ourselves as a faith community after the Vatican II Council. ${ }^{114}$

One of the charges of the USCC's legal department, as well as state conferences and diocesan counsel, is to discern when the state requires the Church to cross a line from accommodation to compromise of its own convictions. ${ }^{115}$ Hence the Church's attorneys at various levels must be aware of and sensitive to the Church hierarchy's prevailing convictions and integrate them into their strategic calculus. ${ }^{116}$

As the USCC and other Catholic-oriented organizations began to work out this post-Vatican II understanding on rights advocacy, they confronted many difficult questions about where to draw these lines. Different areas of law presented different sets of concerns for the Church. Consequently, as we saw with evangelical groups, Catholic rights advocacy has taken many forms over time, from protection of the Church's institutional interests in education to a broader cultural concern over issues such as abortion and the right-to-die, among many others. But for our purposes the important point is that these forms of legal advocacy have been structured not only by an accommodating political environment or available resources, but also by the Church's own ideas about the appropriateness of legal engagement in certain areas of social and political concern.

\section{RELIGIOUS INTEREST GROUP LITIGATION IN ISRAEL AND INDIA}

Preliminary evidence from our American case study indicates that religious groups in the United States opt for litigation for both institutional and ideological reasons. In this section of the article, we suggest that Israeli and Indian interest groups use a similar decision calculus.

As we have already discussed, both Israel and India are traditionally thought of as strong multi-party states where groups play a less prominent role in politics. Yet in both countries some groups, including some religious organizations, have indeed turned to the courts as a means of achieving their objectives. In fact, in Israel since the 1980 s more social, political, and religious groups are using litigation."' And as we shall see, in India too,

114 Id.

115 See id.

116 See id.

117 See, e.g., Jayanth Krishnan, Public Interest Litigation in a Comparative Context, BUFF. PUB. L.J. (forthcoming 2002) (discussing the rise in the use of litigation by women's groups, environmental groups, religious groups, and civil rights groups in Israel). See also Women of 
despite the presence of numerous parties, different interest organizations have occasionally employed the tactic of litigation.

What accounts for this use of courts by specifically religious organizations in these two multi-party states? One explanation may be that in both countries gaining access to the courts is relatively easy. ${ }^{118}$ In both countries, court fees are usually minimal, standing requirements are easy to meet, and in many types of cases representation by a lawyer is not even required. ${ }^{119}$ In cases involving the public interest, groups in both Israel and India are permitted to petition directly the respective Supreme Courts for hearings. ${ }^{120}$

Furthermore, groups in both countries have seen an increase in resources during the past two decades. In Israel one non-profit funding agency in particular (The New Israel Fund) has been especially generous in donating different types of resources to certain religiously oriented organizations. ${ }^{121}$ The Masorti Movement and the Israel Religious Action Council have been two such benefactors. ${ }^{122}$ Likewise, in India several different religious organiza-

the Wall Win High Court Hearing, JERUSALEM POST, Feb 18, 1999 (noting the use of courts by a religious women's organization). See generally Frances Raday, Religion, Multiculturalism. and Equality: The Israeli Case, ISR. Y.B. ON HUM. RTS. 193, $210-227$ (1996); Philipa Strum, Women and the Politics of Religion in Israel, HUM. RTS. Q. 483 (1988).

${ }^{118}$ In Israel, since the 1980's there have been a series of Supreme Court decisions which have facilitated access to the courts, particularly the Supreme Court. See, e.g., Segal v. Minister of Interior, H.C. $217 / 80,34$ (4) P.D. 441 ; Shiran v. Israeli Broadcasting Authority, H.C. 1/81, 35 (3) P.D. 365; Resslet v. Minister of Defense, H.C. 910/86, 42 (2) P.D. 441 . In India petitioners have a constitutional right by way of Article 32 of the Indian Constitution to petition directly the Supreme Court where a fundamental, constitutional right has been violated. See, e.g., S.P. Gupta v. Union of India, AIR 1982 SC 149; D.C. Wadhwa v. State of Bihar, AIR 1987 SC 579; Ratlam Municipal Council v. Vardhichand, AIR 1980 SC 1622; Fertilizer Corporation v. Union of India, AIR 1981 SC 344; People's Union for Democratic Rights v. Union of India AIR 1982 SC 1473. As a side point of interest, "the Indian Supreme Court's jurisdiction is remarkably broad. It has original jurisdiction over disputes between the national government and the states and between different states; it has appellate jurisdiction over criminal and civil cases, ... and it has advisory jurisdiction to render its opinion on any question of law or fact referred to it by the President. The court also has special leave jurisdiction that grants it discretion to hear appeals involving 'any judgment, decree, determination, sentences or order in any cause or matter relating to the Armed Forces.' Thus the Supreme Court may decide nearly any issue that arises in Indian politics." Epp, supra note 25, at 81-82.

119 See, e.g., Carl Baar, Social Action Litigation in India: The Operation and Limitations of the World's Most Active Judiciary, 19 POL'Y STUD. J. 140, 141-42, (1990); Yoav Dotan, Do the "Haves" Still Come Out Ahead?, supra note 36, at 1059, 1063-64; Yoav Dotan, Judicial Rhetoric, Government Lawyers, and Human Rights: The Case of the Israeli High Court of Justice During the Intifiada, 33 L. \& SoC'Y REV. 319 (1999).

120 See id.

121 Literature published from the New Israel Fund (on file with authors).

${ }^{122}$ See id. 
tions have received new funding, primarily from "non-resident Indians" who live in the United States. ${ }^{123}$

It is only reasonable to assume that easy access to courts and an increase in resources are why certain religious groups are more frequently using the legal process. But are these conditions the only factors that matter? Consider that in spite of these seemingly favorable circumstances there is little record in either Israel or India of religious groups using litigation to the same degree that we find in the United States. Systematic litigation campaigns by Israeli and Indian religious groups are simply not present. So even though in theory it appears favorable for religious groups to use courts, only a select few in these countries regularly engage the judicial process.

Over the last two and one half years the first author of this study has made four visits to Israel and one extended trip to India conducting archival research, content analysis of interest group literature, and performing in-depth, semi-structured interviews of a wide array of groups, including certain religious organizations. ${ }^{124}$ The evidence gathered during this fieldwork indicates that in addition to the standard factors typically associated with why religious groups in particular, may or may not choose to litigate, ${ }^{125}$ there are other more ideologically-based reasons that affect the decision-making calculus.

${ }^{123}$ See, e.g., V.H.P. Lashes Out at Church for Baseless Allegations, INDLA TODAY, Nov. 1, 1999; see also South Asian Activists of North America Unite!, at http://www.altematives.cal ceras/17/montreal.htm (last visited Mar. 7, 2002).

${ }^{124}$ We restrict our study to religious groups that work on national issues and are headquartered in Jerusalem and New Delhi. We are sensitive that many "unorganized" or amorphous groups are present in both countries. We also know that these more mass-based groups, as an anonymous interviewee stated, "often lead the way in opening the political space for the rest of us recognized groups" to advance certain policy initiatives. We do not intend to de-emphasize these other groups by only focusing on traditionally structured organized interests. We currently are considering for our next project how best to focus on these other, extremely significant social movements.

${ }^{125}$ As in the United States, litigation in Israel and India is defined as the process by which the law is used to resolve a dispute. Participating in litigation in Israel and India may also range from being an actual member in a lawsuit, to sponsoring someone else's lawsuit, to writing a "friend of the court" brief in support of a lawsuit. 


\section{A. The Power of Ideas in a Comparative Context}

\section{The Case of Israel}

Within Israel there are those organizations-both religious and nonreligious-that have been seeking to reduce the amount of influence the Orthodox Jewish community currently wields over the state. ${ }^{126}$ The Israel Religious Action Center (IRAC) is one such group that combats what it perceives as the Orthodoxy's hegemony over Israeli society. IRAC serves as the legal arm for the Reform Jewish Movement in Israel. ${ }^{127}$ Started in 1987, IRAC explicitly rejects-and fights against-the control the rabbinical Orthodoxy has over issues such as marriage, divorce, burial, and conversion. ${ }^{128}$ IRAC is intimately involved in the "Who is a Jew" issue. Through a special program known as the Legal Advocacy Centers for Olim (LACO), IRAC helps newly arrived immigrant Jews (who often face discrimination from the Orthodoxy) integrate into Israeli society. ${ }^{129}$

IRAC's literature indicates that while the group is involved in a variety of activities, it frequently employs legal tactics. Along with litigating cases in court, it also occasionally submits amici-type petitions on behalf of nonOrthodox Jewish communities in certain cases. ${ }^{130}$ It also works in coalitions with other religious organizations in promoting legal awareness, maintaining legal clinics, offering pro-bono legal advice, and sponsoring lawsuits that promote the rights of cultural, Reform, and Conservative Jews. ${ }^{131}$

${ }^{126}$ It should be noted that the Orthodox community in Israel serves as a political lightning rod within Israel society. As a result of an agreement struck between the Orthodox Jewish community and the State of Israel in 1948, the former was provided with a series of governmental protections, which to this day anger the majority of Israeli citizens. This "status quo" agreement, among other points, stated that the Orthodox community would control issues of marriage and divorce for all Jews in Israel. It also stated that the Sabbath would be a government observed holiday. Furthermore, all state institutions were to observe kashrut, and members of the Orthodox community were permitted to have a separate educational system for their children that was to be funded by the state. For a further discussion of this subject, see EDELMAN, supra note 2, at 48-72.

${ }^{127}$ See Tom Tugend, Wanted: American Civil Rights Lawyers: Advocate of Israeli Pluralism Makes a Pitch for U.S. Lawyers, ZtPPLE, Aug. 28, 2001, available at http://www.zipple.com/ newsandpolitics/israelnews/20001207_civil_rights_lawyers.shtml.

${ }^{128}$ Id. See also Literature published by IRAC (on file with authors) [hereinafter IRAC Literature].

${ }^{129}$ IRAC Literature, supra note 128.

${ }^{130} \mathrm{Id}$.

${ }^{131}$ See id.; see also "Focus on Issues," information sheet published by IRAC. 
The literature of IRAC provides insight into what motivates this organization to employ legal tactics. We learn that IRAC strives for legal and public promotion of religious pluralism, social justice, and human equality. ${ }^{132}$ IRAC's work is based on the belief that these values are intrinsic and stem from a liberal understanding of Judaism. ${ }^{133}$ Furthermore, Uri Regev, the director of IRAC, recently remarked that diversity of faith and the freedom to practice religion in accordance to one's conscience are the true tenets of Judaism and the main goals that IRAC always pursues. ${ }^{134}$

In-depth interviews with two attorneys from the group also shed light on what factors affect whether litigation is used. ${ }^{135}$ For example, the attorneys did not indicate that the country's numerous political parties interfered, competed with, or absorbed the platforms of IRAC. In fact, as one of the attorneys pointed out left-leaning political parties complement, not replace, IRAC's role in Israeli politics. ${ }^{136}$

Of course the attorneys agreed that resources play a role in the decisioncalculus. But because of the relatively inexpensive costs of litigating in the Supreme Court (where most of their litigation activity takes place), resources, in their view, probably play less of a role in appellate advocacy than in the United States. ${ }^{137}$ We also learned that decisions on whether to use litigation depends upon the type of assistance they receive from the country's legislative and bureaucratic institutions. ${ }^{138}$ For many issues that concern IRAC, the attorneys stated that neither the Knesset nor the various ministries serve as effective institutions to redress grievances. ${ }^{139}$ By contrast, the one attorney pointed to how the Supreme Court has actively been involved in protecting

${ }^{132}$ IRAC Literature, supra note 128.

${ }^{133}$ Id.

134 Uri Regev, Religious Freedom: A Struggle for the Jewish Soul, at http://www.irac.org/ article_e.asp?artid=85 (last visited Feb. 26, 2002).

135 To protect their identity, the names of the IRAC attomeys are not used.

${ }^{136}$ First author interview with "Attomey 'A,' " Attorney, IRAC (Sept. 8, 1998).

${ }^{137}$ In Israel, individuals, organizations, or parties may directly petition the Supreme Court when a state action is involved. The Supreme Court of Israel has multiple functions. It serves as the court of last resort (having discretionary jurisdiction) in everyday civil and/or criminal cases. It serves as a court of appeals for serious cases involving civil or criminal offenses. And it serves as a court of first and last resort when it sits as the High Court of Justice (HCJ). The HCJ hears cases that directly challenge the legality of a public body. Public bodies may include public agencies, local authorities, public companies in some cases, private bodies acting in a public capacity, the legislature, and the President. (It is uncertain if the HCJ will hear a case directly against the Prime Minister). For a discussion of the role of the Israel Supreme Court, see Gelpe, supra note 6, at 506-30 (1999).

${ }^{138}$ First author interview with "Attomey 'A,' " Attorney, IRAC (Sept. 8, 1998).

139 Id. 
non-Orthodox rights. This particular individual lauded the historic Brother Daniel case, ${ }^{140}$ where the Israeli Supreme Court decided that it, not the Orthodox-controlled rabbinical courts, would dictate who could qualify as a Jew for purposes of applying for the country's "Law of Return." attorneys expressed satisfaction that the Supreme Court has exhibited the "courage" to venture into legal terrain that many within the Orthodox community believe is beyond the Court's jurisdiction. ${ }^{142}$ (In fact, evidence that the Court currently supports non-Orthodox causes is seen by several recent decisions that appear to interpret Judaism in a broader manner.) ${ }^{143}$

Still what is most interesting is that the IRAC attomeys each stated that another factor was involved in the group's decision to pursue litigation as a course of action. One of the attomeys put it most eloquently. The group's inclusive and accepting Judaic beliefs demanded that they fight to secure the rights of all Jews in the country. ${ }^{14}$ As this attorney noted, members of IRAC are just as religious as the Orthodox in Israel. ${ }^{145}$ IRAC, however, sees Judaism as a pluralistic faith, open to both the Orthodox and non-Orthodox communities. ${ }^{146}$ Thus, if certain Jews are being denied the right to have a voice in how

${ }^{140}$ H.C. 72/62, Rufeisen v. Minister of the Interior, 16 P.D. 2428.

141 Id.

142 First author interview with Attomeys "A" \& "B", IRAC (Sept. 8, 1998).

143 These cases have not yet been translated into English. But see A List of Haredi Grievances, JERUSALEM POST, Feb. 12, 1999. This article summarizes the Court's decisions that the Haredi, or ultra-orthodox, are against. They include: Two Court rulings that disallowed the withdrawal of a kashrut certificate in a public hall that displayed a Christmas tree as well as in another facility that held a New Year's Eve party; a Court ruling that prohibited military deferrals or exemptions for yeshiva students; a Court ruling that prohibited the Jerusalem Religious Council from setting the budget of a political party; a Court ruling that allowed for secular burial; a Court ruling that mandated that women be accepted in a course run by the Employment Service Board; two Court rulings stating that Reform and Conservative members be allowed to sit on religious councils; a Court ruling that allowed a girl to return to a secular school after her father withdrew her; a Court ruling that prohibited moshav rabbis from engaging in certain political tactics; a Court ruling refusing to enforce the wearing of a kippa in a rabbinical court; a Court ruling allowing the registration of Reform conversions; a Court ruling prohibiting rabbis of one sect to distribute holy oil to voters; a Court ruling in favor of holding exams for women pleaders in rabbinical courts; and a Court ruling against giving double subsidies to Bnei Akiva, a religious youth movement. See also Women of the Wall Win High Court Hearing, JERUSALEM POST, Feb. 18, 1999 (allowing women to hold the Torah and wear shawls as they pray at the Western Wall).

${ }^{144}$ First author Interview with “Attorney 'A,' " Attorney, IRAC (Sept. 8, 1998).

145 See id.

146 Id. 
they practice their religion, then on both moral and religious grounds, the group believes it must legally do whatever it can to oppose this infringement-whether that means holding rallies, protesting, or going to court. ${ }^{14}$

This comment suggests that religious ideology-in this case, liberal Judaic ideology-indeed plays an important motivational role in the tactical decisions of IRAC. While resources and institutional factors may serve as necessary conditions for understanding litigation strategies, they are simply not sufficient. Religious ideas certainly are key in whether or not IRAC selects litigation as a public policy tactic.

The impact of religious ideology in organizational decision-making is not just restricted to IRAC. A study of another religious group, the Masorti (Conservative) Movement, also reveals the powerful impact ideas have on tactical choices. The Masorti Movement officially came into existence in Israel in 1979. ${ }^{148}$ Born out of the unification of two umbrella organizations, the United Synagogue of Israel and the Rabbinical Assembly of Israel, the Masorti Movement today has over fifty affiliated congregations around the country. ${ }^{149}$ The first Conservative group in Israel, the Emet Ve'emunah, was founded by German Jews in British Palestine in 1936. ${ }^{150}$ As time passed, membership within the entire Conservative movement grew; "immigrants from English speaking countries who were familiar with Conservative ideology and the positive expressions of a pluralistic society"151 slowly began to make-up much of the community. The organization currently asserts that its membership draws upon individuals and families from a wide array of backgrounds as well as ethnic communities (both Sepharadim and Ashkenazim). In fact, the Masorti Movement frequently works together with the Reform Movement in fighting the Orthodoxy's control over the areas of marriage, divorce, conversion, and burial. ${ }^{152}$

147 See id.

148 Literature published by the Masorti Movement, available at http://www.masorti.org/ mason/about/history.html (last visited Feb. 27, 2002) (literature on file with authors).

149 See id.

150 See id.

151 Id.

152 Mission Statement published by the Masorti Movement in Israel, at http://www.masorti. $\mathrm{org} / \mathrm{mason} / \mathrm{about}$ (last visited Feb. 15, 2002) (literature on file with authors) [hereinafter "Mission Statement"]. Note, similar to the demographics of Reform Jews, more Masorti Jews live outside of Israel than within the country. All Jews in Israel are subject to Orthodox rabbinical courts when it comes to marriage and divorce. Only recently has the state, primarily at the Court's direction, loosened the Orthodoxy's control over how Jews may be buried. On the issue of conversion, the state, again at the Court's behest, seems to be moving in the direction of allowing Masorti and Reform rabbis conduct such ceremonies. For a more detailed 
The Masorti's mission statement notes that the organization is committed to the Torah, ideas of tolerance, and the principles of Zionism. The Masorti Movement strives to adhere to the basic teachings of Jewish law, the Halachah, while at the same time, coping with the challenges and realities presented by modern society. The Masorti Movement is deeply committed to Zionism, but also stresses throughout its literature that tolerance and mutual respect for various religions and cultures is at the heart of the Judaic tradition. ${ }^{153}$

The Masorti Movement promulgates these values by establishing Conservative academic institutions as well as religious schools and camps. ${ }^{154}$ The group's other tactics include social awareness programs, advertising and publication, and the holding of peace protests, conferences, and rallies. As far as formal institutional tactics, the Masorti Movement is involved in parliamentary and bureaucratic lobbying, although it usually defers to its party-allies to advance its causes in these institutions. ${ }^{155}$

In terms of legal mobilization, the group does not employ litigation as a primary, or for that matter as a secondary, tactic. In most cases the Masorti Movement will rely on individual public interest attorneys and IRAC to fight its legal battles, especially in cases where the state imposes private religious observance through legislation. ${ }^{156}$ We sought to inquire why this Conservative Jewish group mainly refrains from directly using litigation. In two separate interviews with a Rabbi who is a main policy leader of the Masorti Movement, it was learned that resource limitations and perceived benefits gained by partyallies at the bureaucratic and legislative levels minimize the feeling that the group needs to use litigation. ${ }^{157}$

But the Rabbi indicated that other factors are at work as well. According to the Rabbi, being involved in litigation is a very contentious process. ${ }^{158}$ Instead, the Conservative Movement prefers to promote the ideals of compromise and tolerance. In a sense, going to court leaves the proverbial bad

discussion of this subject, see Galanter \& Krishnan, supra note 2.

${ }_{153}$ See Mission Statement, supra note 152.

154 See Masorti Movement of Israel, at http://www.masorti.org/mason/about/about.html (last visited Feb. 27, 2002).

155 Interview with high ranking policy official within Conservative Movement (Sept. 9, 1998), whose congregation is one of the largest in Jerusalem.

${ }^{156}$ Id.

157 Interview with high ranking policy official within Conservative Movement (Sept. 9, 1998), whose congregation is one of the largest in Jerusalem; second interview conducted Apr. $13,2001$.

${ }^{158}$ See id. (Sept. 9, 1998). 
taste in the group's mouth, and that is simply not what the organization is about. ${ }^{159}$ When asked, however, why the group occasionally involves itself at all in the legal process, the response was rather interesting. The Rabbi stated that litigation is always a last resort and that it is typically used when other approaches have failed. Yet he stressed that the decision-making process is much more complex than whether or not the group is 'disadvantaged' in the other branches of government. ${ }^{160}$ In most cases the group sees litigation as a conflict-ridden procedure that does not fall into line with its ideological beliefs. However, so long as this conflict-oriented, litigious way of resolving a dispute is not an immediately employed tactic, then the group can know that it is at least trying its best to remain true to its principles and faith. ${ }^{161}$

The study of both the Reform and Masorti Movements indicates that ideology plays an important role in whether or not these religious organizations enter into litigation. Data from the last of our Israeli religiously basedgroups continue to support this central argument. The Women of the Wall (WOW) are an organization of Orthodox women who have fought to pray at the Wailing, or Western Wall (the Kotel in Hebrew), since the end of $1988 .^{162}$ The Western Wall is arguably the holiest of all religious sites to Jews. The Wall is the last remaining remnant of the Herodian Temple that was destroyed by the Romans in 73 A.D. - the date that marked the beginning of the Jewish diaspora that lasted until the founding of the Israeli state. ${ }^{163}$

The WOW have offended many Orthodox Jews because of how they pray while at the Western Wall. ${ }^{164}$ The WOW wear prayer shawls and recite aloud from the Torah. ${ }^{165}$ While this type of practice is customary for men, many Orthodox Jews consider it to be a violation of the Halacha for women to act in this manner. But the WOW wish to participate fully within the Orthodox community; they do not seek to be second-class citizens within their own religion. ${ }^{166}$ Protests against the WOW have ranged from verbal beratement to violence, including spitting and throwing excrement at the women. ${ }^{167}$

159 See id.

160 See id. (Apr. 13, 2001).

161 See id. (Sept. 9, 1998).

162 See Frances Raday, The Fight Against Silencing: The Case of the Women of the Wall, in WOMEN OF THE WALL (publication forthcoming) (on file with author) [hereinafter Raday, Fight Against Silencing].

${ }^{163}$ See generally MARTw GILBERT, ISRAEL: A HISTORY (1998).

${ }^{16}$ Raday, Fight Against Silencing, supra note 162, at 1-11.

165 See id.

${ }^{166}$ First author interview with Frances Raday, attomey for the WOW, Sept. 27, 1998.

${ }^{167}$ Raday, Fight Against Silencing, supra note 162. 
The WOW have been engaged in litigation for years. They recently succeeded in persuading the Supreme Court to issue an order affirming their right to pray at the Wall. ${ }^{168}$ But what motivated the group to rely on litigation as a tactic to advance their goals? There were several reasons, according to the group's attomey Frances Raday. For one thing, the group sought to publicize its cause within a legitimate state forum. ${ }^{169}$ The women wanted the Israeli society to see how unfairly they were being treated by many of the Orthodoxy's elite. ${ }^{170}$ The group also received little substantive assistance from those in government or in civil society; thus there were few other alternatives aside from the courts. ${ }^{171}$

In addition, Raday stated that the women's deep sense of commitment to their interpretation of Judaism was a crucial driving force behind their decision to litigate. As she notes in a recent article on the WOW, the group is "struggling for feminist expression within the religious context. ... [Their legal] struggle against exclusion from the public sphere . . . is now being reenacted in the context of religion." ${ }^{172}$ The WOW, by using the law as a tactical device, are seeking to redefine their identity within Orthodoxy community.

168 The following information is obtained from Raday, supra note 162, 1-11. Actually this decision to allow the WOW to pray at the Wall came after several different sets of events. After failing to seek redress from the bureaucracy and legislature, the WOW filed a petition in the Supreme Court in 1996, sitting as the High Court of Justice. The Court in this case, commonly referred to as Hoffman I, rejected the WOW's petition. The Court although rejecting the WOW's petition still recommended that the government find a solution whereby the WOW could pray while not offending other worshipers. The government appointed a commission which decided after two years that while the WOW could pray in their preferred manner, they could not do so at the exact site of the Wall. The government then appointed a follow-up commission which rejected the first commission's "solution" out of security concerns for all those involved. A third commission (the Neeman Committee) was then established which decided that the best place for the WOW to pray was an alternative site near the Wall known as Robinson's Arch. During all of these commissions' findings the WOW repeatedly petitioned the Court, but only after the Neeman Committee issued its findings did the Court make a final ruling. In 2000 the Court held that forcing the WOW to pray at altemative sites was inconsistent with the basic principle of equality. The Court in this case, now known as Hoffman II, ordered the government to accommodate the rights of the WOW to pray at the Wall. (After the Court's second ruling, the government asked an expanded panel of nine justices to hear the case, and this request was granted. At the time of this writing, no decision had yet been issued by the ninemember panel.) See id.

${ }^{169}$ First author interview with Frances Raday (Sept. 27, 1998); follow up interview Feb. 20, 2000.

${ }^{170}$ See id.

171 See id.

${ }^{172}$ Raday, Fight Against Silencing, supra note 162. 
Interestingly, they do not see themselves as radicals or revolutionaries. They do not ask to pray directly alongside the men; out of respect, they even purposefully segregate themselves to the ezrat nashim, or a separate women's section of the Wall. ${ }^{173}$ And, they do not even recite those prayers that demand the presence of at least ten men (minyan prayers). ${ }^{174}$ What they do seek, however, is to worship freely in the manner of their choice. There is a desire to express their sense of religiosity without fear of a patriarchal hegemony demanding retribution. Therefore, in an effort to regain their dignity and identity as faithful servants to God-which they believe has been stripped from them by Orthodoxy's outdated traditions, they have turned to the legal process in an effort to have their rights protected.

\section{The Case of India}

Like Israel, India serves as another optimal case to test the applicability of the standard theories. With good cause there is reason to believe that the country's multi-party system and delay-ridden, overburdened courts contribute to the reason that there are such low rates of interest group litigation. ${ }^{175}$ Moreover, the fact that most groups lack sufficient resources to mount continued litigation campaigns is also seen as a huge impediment. ${ }^{176}$ But as we mentioned earlier encoded within the Indian legal system are principles that allow groups to file cases involving issues that impact public policy and the public interest directly in the Supreme Court. ${ }^{177}$ Such claims in fact can be done quite cheaply and without even formal legal representation. ${ }^{178}$ Perhaps then this explains why some groups have opted to pursue the route of litigation.

173 See id.

174 See id.

175 See, e.g., EPP, supra note 25, at $82-8395.99$ (showing data that the Supreme Court disposed of over 56,000 cases, but still had on its docket over 185,000 awaiting decisions as well as noting that in general groups do not have the wherewithal to sustain such long delays in the judicial process). Also note that a relatively recent report to Parliament showed that nearly 2.9 million cases remained pending in the country's various state high courts. See Bureau of Democracy, Human Rights, and Labor, U.S. Department of State, INDIA COUNTRY REPORT ON HUMAN RIGHTS PRACTICES FOR 1997 (1998), available at http://www.state.gov/www/global/ human_rights/1997_hrp_report/india.html (last visited Mar. 7, 2002).

5.

${ }^{176}$ Epp, supra note 25, at 95-99. See also GALANTER, COMPETING EQUALITIES, supra note

17 Art. 32, Constitution of India.

${ }^{178}$ See Baar, supra note 119, at 140-42. 
But if our focus is on religious organizations, can we explain whether or not these groups litigate solely in terms of institutional and resource factors? To answer this question, we focus on three types of groups in India: a Hindubased organization, a Muslim group, and a Christian movement. The first of our groups is the Arya Samaj, a Hindu, Vedic organization founded in $1875 .{ }^{179}$ The Arya Samaj has multiple branches within and outside of the country. ${ }^{180}$ While the group claims not to be steeped in the fundamentalist, Hindutva tradition, it does believe that its members should closely follow the ten basic teachings of the holy Hindu scriptures, the Vedas. ${ }^{181}$ The membership of Arya Samaj numbers in the thousands; no accurate figure is currently available. Although often accused of espousing Hindu superiority, the group claims that it only seeks to unify Hindus by abandoning the divisive institution of caste and promoting principles of equality, liberty, education, social welfare, and political representation for all people. ${ }^{182}$

In interviews with one of the leading Swamis (spiritual leaders) in the movement, the first author gathered extensive information on the types of tactics the group practices. To this day, one of the most frequently employed activities includes the holding of public conferences and seminars. ${ }^{183}$ Leaders of the organization invite individuals from the grassroots levels and educate them on topics involving religion, politics, economics, and society. ${ }^{184}$ In addition, the group publishes and distributes volumes of books, journals, and newspapers. ${ }^{185}$ The group occasionally holds rallies and public demonstrations promoting its message. ${ }^{186}$ And leaders within Arya Samaj meet with bureaucrats and legislators in an effort to persuade these officials to adopt policies that fall into line with the group's central beliefs. ${ }^{187}$

${ }^{179}$ Literature Published by Arya Samaj. See http://ww.whereisgod.com (last visited Mar. 7, 2002) [hereinafter Lit. of Arya Samaj].

180 See id.

181 The teachings include: God is the eternal, unseen sustainer of all; God is all-loving, allknowing, and all-being and that worship must be to Him alone; the Veda is the scripture of true knowledge; Truth should always be uttered; Righteousness should always be pursued; Benevolence should always be promoted; Laws of science, spirituality, and physics are truth; Individualism and Altruism must be practiced; All people must subordinate themselves to the laws of society, so long as these laws promote the well-being of all. See id.

${ }^{182}$ See id. See generally Veena Dua, The Arya Samaj in Punjab Politics, (Vedams: New Delhi, 1999).

${ }^{183}$ First author interview with Swami from Arya Samaj (Dec. 15, 1998).

184 See id.

185 Lit. of Arya Samaj, supra note 179.

186 See id.

187 First author interview with Swami from Arya Samaj (Dec. 15, 1998). 
The Swami being interviewed for this study also noted how there was a "disgust" within his organization over the way that other prominent religious coalitions, including the Sangh Pariwar (of which the ruling Bharatiya Janata Party is a member), have been manipulating the teachings of Hinduism for purely self-interested motives. ${ }^{188}$ He stated that his group wished not to be associated with these "character-less" organizations. ${ }^{189}$

The Swami also mentioned that over the past twenty years Arya Samaj has been involved, albeit in infrequent doses, in one type of political tactic: litigation. Arya Samaj, in rare instances, has sponsored cases on behalf of quarry workers and laborers who work primarily on government construction projects. ${ }^{190}$ As the Swami noted his organization observed how these (typically) low-caste individuals were being treated by the government. ${ }^{191}$ Their pay was low, their working conditions were abominable, and the risk to their health was immense. ${ }^{192}$ Under the principles of the Vedas, it was the duty of Arya Samaj to act on behalf of these underprivileged citizens. ${ }^{193}$ According to the Swami, since the government is filled with self-interested parties and the bureaucracy is highly corrupt, the judiciary remains the only institution to which the group can turn. When pressed on how the group could afford the time (average length of lawsuits in India is one of the longest in the world) or the money to litigate such matters (the group uses one of the country's most expensive Supreme Court attorneys), the Swami indicated these factors were, of course, considerations. But he concluded by saying that he and his fellow members of Arya Samaj feel a deep sense of moral and religious responsibility to act on behalf of those most in need. ${ }^{194}$

Tactical decisions based on religious doctrine can also be seen in the study of the Jamaat-e-Islami Hind (hereinafter Jamaat), arguably the country's largest Muslim interest organization. Started in 1948, Jamaat not only has

188 See id.

189 Id.

190 For a complete narration of this long litigation, see Oliver Mendelsohn, Life and Struggle in the Stone Quarries of India: A Case-study, 29 J. COMMONWEALTH \& COMP. POL. 44 (1991). As Mendelsohn documents, Arya Samaj represented the workers and sought to enforce the provisions of the Bonded Labour System (Abolition) Act of 1976, which was a piece of Emergency legislation that statutorily codified the Constitutional prohibition against forced labor. Although the laborers won an important victory in court, realistically little changed for the many impoverished Indians who continued to eek out an existence by working in deplorable conditions as forced laborers.

191 First author interview with Swami from Arya Samaj (Dec. 15, 1998).

192 See id.

${ }^{193}$ See id.

194 See id. 
offices in almost every state in the country and thousands of members, but it is an international organization as well. Its Pakistani branch serves as the world headquarters. ${ }^{195}$ During a meeting with Mahmood Khan, ${ }^{196}$ a leading policy activist who also is the leader of a state branch, the first author learned the group is involved in four main types of policy activities: (1) holding seminars, (2) sponsoring symposiums with government and societal leaders, (3) publishing materials that promote the group's message, and (4) working at the grassroots level to help the poor build homes, harvest crops, and improve the infrastructure of village life. ${ }^{197}$ (Khan vigorously denied his organization performs these social welfare services with the ulterior motive of converting needy individuals to Islam).

As far as institutional tactics, Khan stated Jamaat frequently works with and supports political parties, so long as these parties are active in protecting the rights of minority religious communities within the country. ${ }^{198} \mathrm{Khan}$, however, noted his organization is rarely, if ever, involved in litigation. When asked why Jamaat did not employ litigation on a regular basis, especially in light of the fact that Muslims face some of the harshest discrimination in the country, he made a few keen observations. First, he noted the resources of the group are always limited; it is more efficient to rely on specialists such as public interest groups to fight legal battles on Jamaat's behalf. ${ }^{199}$ Second, by being directly involved in litigation, Jamaat would be thrust into the public spotlight, something that a minority group trying to promote the teachings of the Koran in a Hindu-dominated society attempts to avoid. ${ }^{200}$ Third, he repeatedly stated that Jamaat is an organization interested in promoting interfaith harmony. (In 1993, for instance, it joined a multi-religious umbrella

195 Literature produced by Jaamat-e-Islami Hind (on file with authors). It is important to keep in mind that the Jaamat-e-Islami Hind maintains that it is a peaceful organization. While it recognizes that there may be other organizations around the world (particularly in Pakistan) that have a similar name, the Indian Muslim official interviewed for this study, steadfastly proclaimed that the Jaamat-e-Islami Hind remains an organization opposed to violence and those tactics that are extra-legal in nature. This official, who we shall refer to as "Mahmood Khan" (to protect his identity), repeatedly stressed that in no way does the Jamaat-e-Islami Hind support anything but democratic means to achieve its goals.

196 Id.

197 First author interview with Mahmood Khan (Nov. 4, 1998).

198 See id. See also Jamant-E-ISLAMI HIND, POLICY AND PROgRAMme (1999) (a detailed policy statement published by the organization outlining its tactics, principles, and agenda) (on file with authors).

199 See id.

200 See id. 
coalition known as the Forum for Democratic and Communal Amity.) ${ }^{201}$ The teachings of the Koran, according to Khan, stress tolerance and reconciliation, not confrontation. ${ }^{202}$ In his view, many of Jamaat's members tend to see the courts as too aggressive an arena and one not conducive to achieving the group's objectives. In other words, the confrontational way the system is structured makes it extremely difficult for differing sides to reach an amiable solution. ${ }^{203}$ Thus, not surprisingly, the group opts to avoid directly participating in litigation whenever possible.

At the same time, however, Jamaat views the judiciary as having an important function. On those occasions when Jamaat wishes to promote or legitimize an issue to the public, it will seriously contemplate using litigation. The courts, because of their unique position in society, provide the organization with an opportunity to generate legitimacy and respect for a cause it is seeking to advocate. For example, Khan stated that the Jamaat of today is much different than the Jamaat of years past. ${ }^{204}$ According to Khan, many non-Muslims have outdated perceptions of his community; many do not know that the modern-day Jamaat is both plural and all-inclusive. He noted that recent legislation and governmental action that negatively impact Musliminterests are based upon the misunderstanding of the Muslim community and of Islam in general. ${ }^{205}$ When such government action occurs, the group has sought legal redress, not just for the purposes of "winning," but also to clarify to the public the causes which Jamaat supports and the true tenets of Islam.

The final group in our comparative study involves examining the Christian Institute for Study of Religion and Society (CISRS). CISRS is one of the country's well known Christian-based interest organizations. In addition to its headquarters in New Delhi, CISRS has offices in Bangalore, Calcutta, Madras, and Bombay. ${ }^{206}$ The organization claims not to have exact figures on its membership, but it stresses that it has drawn over one hundred thousand supporters in recent CISRS-sponsored peace rallies. CISRS is a member of many Christian umbrella groups in the country, including the Indian National Council of Churches, the World Council of Churches, and the All India Christian People's Forum. ${ }^{207}$.

\footnotetext{
201 See id.

202 See generally KHURSHD AHMAD, ISLAM AND THE WEST (2d ed. 1995).

${ }^{203}$ First author interview with Mahmood Khan (Nov. 4, 1998).

204 See id.

205 See id.

${ }^{206}$ First author interview with Joseph Varghese (Nov. 4, 1998).

207 Id.
} 
Joseph Varghese is a key leader within CISRS. The first author conducted an in-depth interview with Varghese. According to Varghese, along with being involved in publications and coordinating conferences, CISRS lobbies members of the Lok Sabha (India's national parliament). ${ }^{208}$ CISRS is interested in seeing legislation passed that protects Christian converts. ${ }^{209}$ Many of these Christian converts were formally members of the "untouchable" caste who used to receive government allocated benefits because of their historically deprived socio-economic status. Upon converting to Christianity, however, the former untouchables have seen these benefits disappear, primarily because the state typically does not recognize Indian Christians as needing social welfare assistance. ${ }^{210}$

Varghese indicated that while CISRS lobbies legislators, the group rarely employs litigation as a tactic. As he remarked, it is one thing for him to try to persuade elected officials, but it is quite another to engage in a tactic that many see in a negative light. ${ }^{211}$ Varghese explained that the process of litigation is viewed very cynically by much of Indian society. Because CISRS is interested in presenting a benevolent image to the public it is hesitant to employ a tactic that may engender hostility and resentment. The group's particular religious identity, in Varghese's view, labels if not stigmatizes CISRS. The leaders' tactical decisions, as a result, need always to be carefully pondered. ${ }^{212}$

With this said, Varghese noted that in certain circumstances the group does use litigation as a means of promoting CISRS' mission. Whereas lobbying legislators may lead to favorable legislation and holding rallies might draw passing attention of a particular event, no other tactic aside from litigation allows for the opportunity both to fight for justice and to publicize the group's raison d'etre within such a respected state forum. Especially with the recent wave of communal attacks on Christians (by mainly fanatic Hindu nationalists), there is even more of a need to make the public aware of who Indian Christians are and the principles for which they stand. ${ }^{213}$

${ }^{208} I d$.

${ }^{209}$ Id.

${ }^{210}$ Id. See GALANTER, COMPETING EQuAlmitis, supra note 5 (providing an extended discussion of this subject as well as a wonderful analysis of decisions handed down by various courts regarding this issue). See generally ESSAYS IN CELEBRATION OF THE CISRS SilveR JUBILEE (Saral K. Chatterjee ed., 1983).

211 First author interview with Varghese, supra note 206.

${ }^{212}$ See id.

${ }^{213}$ See id. 


\section{CONCLUSION}

The evidence marshaled in this study supports the general argument that conventional theories of group litigation only partially explain the tactical decision-calculus of religious interest organizations. From our American case study, we see that the noticeably increased presence of evangelical groups in court and the relative constancy of the Catholic Church relates not only to the political environment and available resources but to an additional factor rarely considered by others who study this important area: religious ideas. Whether it is through the sponsorship of cases, submission of amici curiae, or actual participation as litigants, religious convictions help structure the choice to use litigation among these groups. Our Israeli and Indian case studies reveal interesting comparative findings as well. In Israel, the research suggests that the ideas to which a group subscribes also influences whether that group will interact with the courts. In India, the country with the overall lowest rates of litigation of the three, we see that institutionalist factors (such as lack of resources) certainly account, in large part, for why religious organizations so rarely enter into litigation. As our data indicates, however, it seems that when religious interest groups in India contemplate litigation they often turn to their religious teachings; their ideas and attitudes toward religious beliefs play a crucial role in the decision-making process.

There are many issues that remain to be tackled, including a systematic analysis of the relative weight of institutional, resource, or ideational determinants of legal mobilization. Moreover, this study has been limited to certain religious groups; it leaves open an empirical question regarding the possibility of generalizing to other groups in various national settings. Yet the analysis takes a first step towards introducing a framework for combining a range of factors as explanations for legal mobilization, most importantly the role of ideas in shaping legal activity. 
